\title{
ドラフトチューブ付噴流層の流動特性と応用技術
}

\section{Flow Characteristics of Draft Tube Spouted Bed and Its Application}

\author{
幡手 泰 雄 ${ }^{*}$, 伊地知和也 *, 上村 芳 三* \\ Yasuo HATATE* ${ }^{*}$ Kazuya IJICHI* Yoshimitsu UEMURA*
}

Key Words : Spouted Bed, Draft Tube, Bypassing Flow, Solids Circulation

\section{はじめに}

図 1 に典型的な流動層と噴流層の概略図を示す。噴 流層は1955年の Mathur らの穀物の乾燥に関する報 告 ${ }^{1}$ 以来盛んに研究が行われ, Mathur の有名な成 書 ${ }^{2}$ 等に示されているように, 乾燥以外に混合, 造 粒, コーティングなどのプロセスに使われており，多 くの報告がなされている。この装置は低い操作圧力, 粒子の安定した動き, また操作の容易さという点で優 れており, $1 \mathrm{~mm}$ 以上の比較的大きな粒子の流動化や 混合に用いられ, 特に穀類の乾燥装置として開発研究 が行われている。一般的な粒子の流動化の観点で言え ば，いわゆる Geldart の分類で D粒子のうち，流動

\section{6 年 12 月 5 日受付}

$*$ 鹿児島大学工学部応用化学工学科

（テ890 鹿児島市郡元1-21-40） TEL. 099-285-8355

Dept. of Appl. Chem. \& Chem, Eng., Fac. of Eng., Kagoshima

Univ., (1-21-40 Korimoto, Kagoshima-shi 890) 〈著者紹介〉

\section{幡手康雄}

昭和 42 年九州大学工学部卒, 九州大学助手を経て昭和 49 年鹿児島大 学助教授、昭和 63 年より教授, 昭和 47 年工学博士。

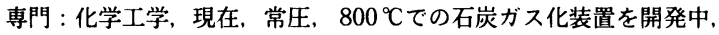
他に機能性無機, 有機微粒子の製造や焼酎等について “化学工学” の範囲で研究を進めている。

伊地知和也

昭和 44 年鹿児島大学工学部卒, 昭和 47 年鹿児島大学助手, 平成 4 年 鹿児島大学助教授, 平成 3 年博士 (工学)。

専門 : 流動層工学, 粉粒体工学, 特殊流動層のドラフトチューブ付 き噴流層の流動特性およびその応用について研究中, 他に、ビルド アップおよびブレークダウン方式による微粒子製造の研究に取り組 んでいる。

上村芳三

昭和 52 年東京工業大学大学工学部化学工学科卒業, 三井東圧化学(住) を経て昭和 58 年鹿児島大学助手, 平成 2 年同助教授。平成 2 年工学 博士。

専門: 触媒及びエネルギー工学, 高分子工学。最近は, 水素吸蔵合 金を利用した膜分離型反応器による二酸化炭素の資源化，水性会合 性高分子の分子設計, リサイクルポリマーの熱分解による資源化等 に取り組んでいる。
化の困難となる粒子が噴流層に適していると言われて いる。これは流動層で流動化できるならその方がよい ということで，噴流層の気固接触装置としての位置付

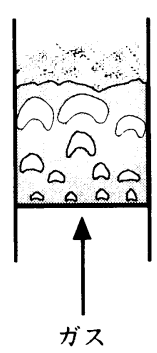

流動層

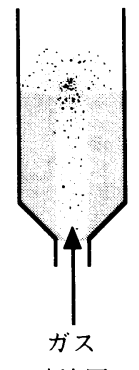

噴流層
図 1 代表的な流動層と噴流層

けを表すものである。噴流層は, 通常ガス吹き込み口 ノズルから流入したガスのうち，30〜70\%が中央部 に形成された噴流部を通過し，固体粒子とあまり接触 することなしに流出するので, 当然気固接触装置とし て流動層と比較した場合は不利になる。しかしなが ら，粉体空気輸送類似の挙動を示す噴流部之移動層の 流動特性を持つアニュラス部という流動層では実現不 可能な形態は, 前者は輸送, 後者は反応場として利用 した場合には極めて優れた（流動層を越えた）装置に もなり得ると考えられるのである。このような特質 は，図2で示すような噴流層の中央部にドラフトチ ューブを備え付けた，ドラフトチューブ付き噴流層と することでさらに強調される。すなわち，ドラフトチ ューブを付けることで噴流部高さに制限がなくなり， また噴流部とアニュラス部との粒子の交換もなくな る。この事は粒子の循環速度や滞留分布が均一化する ことを意味しており，またドラフトチューブを備えた 


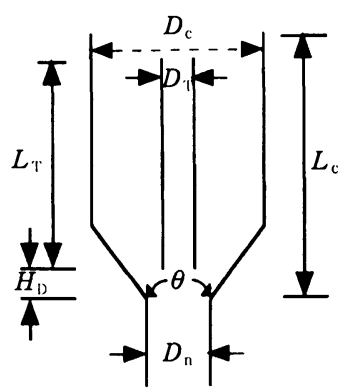

図 2

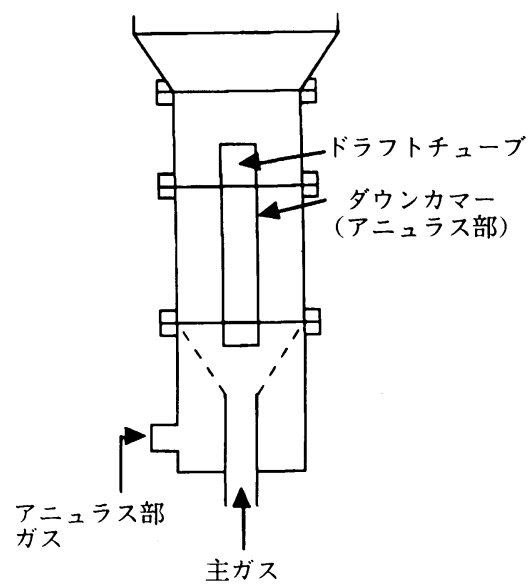

図 3 ドラフトチューブ付噴流・流動層

事で新たに加わった装置因子 $H_{\mathrm{D}}$ や $D_{\mathrm{T}}$ などを変化さ せれば，容易に粒子循環速度をコントロール出来ると いうように, 装置特性が著しく向上したということが 出来る。また，アニュラス部のガス流量を増大させ （さらに，流動化させ）るため考案された図 3 のよう な中央部のノズル吹き込み以外に側面コーン部からも ガス（異種ガスも可）を吹き込むことが出来るタイプ のドラフトチューブ付き噴流・流動層では，異なった 装置特性が期待できる。事実, 著者らが現在開発中の 「蓄熱粒子循環型石炭ガス化装置」は，この一つの応 用技術であるが，この場合には，ドラフトチューブ部

（噴流部）は燃料ガスを燃焼させることにより，燃焼 部としても作用し，熱を蓄熱した循環粒子の輸送管と して使われている。また，アニュラス部は完全な移動 層と見なせるので, 逆混合か激しい流動層に比べて, 格段に反応（水蒸気と石炭とのガス化反応）効率が良 くなり, 従来の石炭ガス化装置にみられないような高 水素含有ガスを取り出すことが出来るようになってい る。

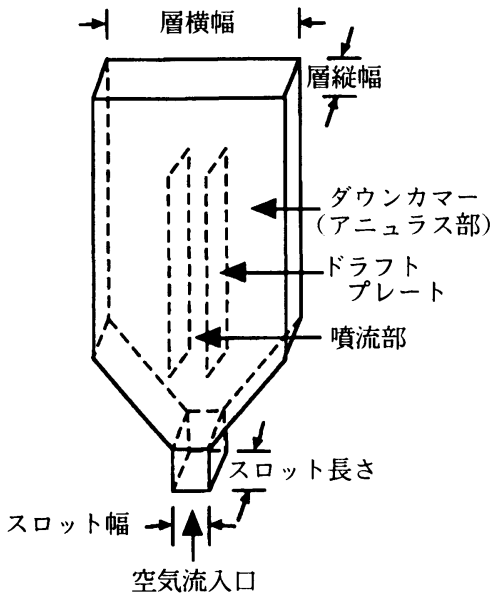

図4 スロット型噴流層装置

上述の石炭ガス化装置も厳密に言えば図 2 に示す典 型的なドラフトチューブ付き噴流層とは言い難く, 用 途に応じて変形改善したドラフトチューブ付き噴流・ 移動層ということが出来る。ここでは，最初に，種々 の形式のドラフトチューブ付き噴流層について概説 し, 穀類の乾燥装置として発展してきた歴史的背景を 考慮して, 伝熱特性に関する最近の研究を簡単に紹介 することとする。比較的詳細な研究が行われ成果も上 がりつつあると思われる粒子循環速度等の流動特性 や，実用を目指した応用技術の研究に関しては，章を 改めて紹介していく。

種々のドラフトチューブ付き噴流層 Whiting ら

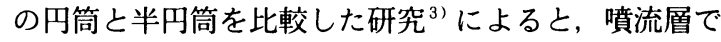
は噴流挙動に及ぼす壁効果の影響は余り考えなくて良 いことから，二次元ドラフトチューブ付き噴流層も少 し修飾すれば実用的意味を持ってくる。Mujumdar ら ${ }^{4)}$ は, 通常, 円筒形で操作される装置を矩形とし, 入りロノズルもスロット型にすることで，ドラフトチ ューブ付き噴流層の大きな問題であるスケールアップ に容易に対応出来るとしている。Law-Kwet Cheong ら ${ }^{5)}$ は，図4に示したスロット型噴流層（横 $0.202 \mathrm{~m} \times$ 縦 $0.05 \mathrm{~m} \times$ 首高さ $0.85 \mathrm{~m}$ ）装置について, ピーナツ，トウモロコシ，大麦，小麦を用いて実用的 な観点から多くのデー夕を蓄積した。Kalwar ら ${ }^{6,7)}$ は, 図 4 で示したドラフトチューブ付き噴流装置の, スケールアップ上問題になる壁効果を調べるため, 装 置特性に及ぼす種々の装置, 操作因子の影響を検討し た。安定噴流化速度は, 実験規模装置（横 $0.05 \mathrm{~m} \times$ 縦 $0.04 \mathrm{~m} \times$ 層高さ $1.5 \mathrm{~m} ）$ の方がパイロット規模装置 （横 $0.75 \mathrm{~m} \times$ 縦 $0.47 \mathrm{~m} \times$ 層高さ $2.0 \mathrm{~m} ）$ より小さくてす 


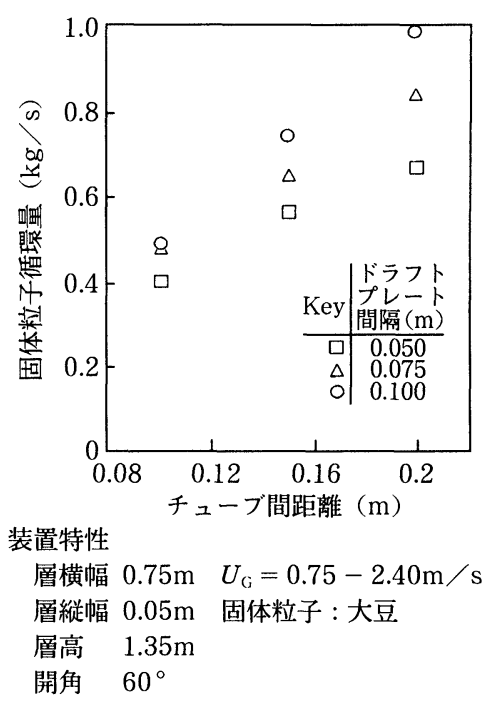

図5固体循環速度に及ぼすチューブ間距離の影響

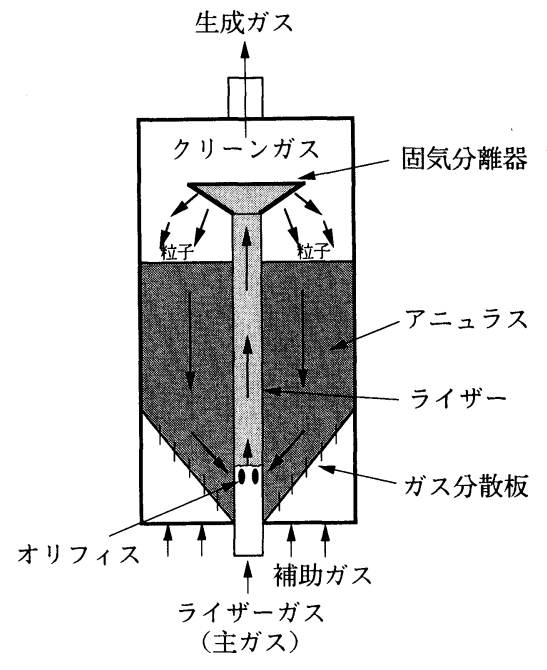

図 6 内部循環型流動層の概略図

むこと, しかし実験ユニットは壁効果のため粒子循環 速度（アニュラス部の粒子速度として検出）がパイロ ットより小さいこと, また縦幅を増すとドラフトチ ューブ内での空気流速の均一化の達成が難しくなる以 外は, スケールアップは容易に行うことが出来ること を明らかにした。この場合, 圧損, 最小噴流化速度及 び粒子循環速度の装置, 操作因子による相関式を提出 した。図 5 はパイロットの実験結果の一例である $\left(U_{\mathrm{G}}=0.75 \sim 2.4 \mathrm{~m} / \mathrm{s}\right)$ 。この装置に関連するものと しては，1986年ガスを脈流として流入させドラフト チューブ内で強力なせん断力を発生させることで, 連

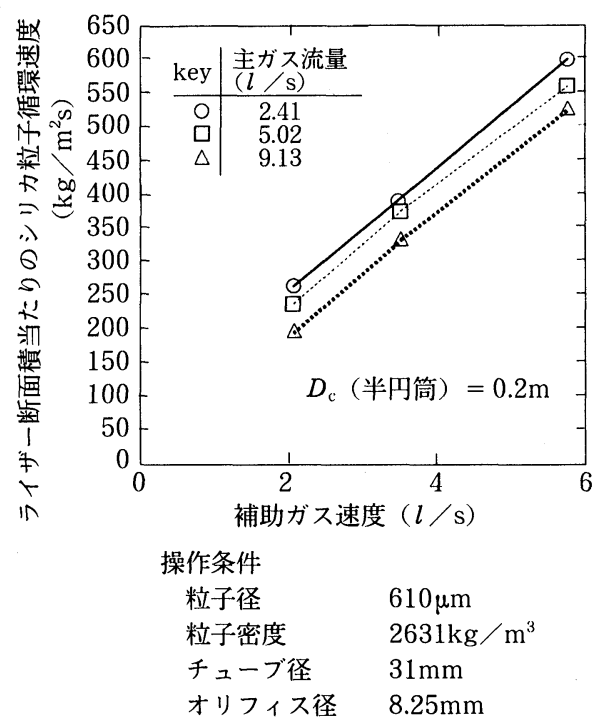

図7 ライザー断面積当たりの粒子循環 速度に及ぼす補助ガス速度の影響

続的に放射性核物質を効率良く混合する装置が特許出 願されている ${ }^{8)}$ 。

ガス流速や粒子循環速度のより正確なコントロール を可能にし，アニュラス部の気固接触効率を上げるた

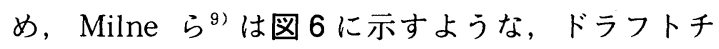
ューブ下部にアニュラス部からの粒子流入用のオリフ イスをもち, 上部にサイクロン用気固分離器を付し, またコーン部に垂直に多数の小孔を設けてアニュラス 部をスムーズに流動化させる装置（内部循環型流動 層）を発展させた。半円筒による基礎研究を行い, た とえば図 7 の結果を得た。横軸は補助ガス（アニュラ ス部への吹き込みガス）速度を表しており，縦軸はラ イザー（ドラフトチューブ）断面積当たりの粒子循環 速度を表している。オリフィス孔を通じて補助ガスの 大部分がライザー（ドラフトチューブ）内に入り（図 省略), 補助ガス速度を変えることでほとんど直線的 に粒子の循環速度を制御できるという結果を得た。こ のような装置は，（急激な加熱速度を達成するため の）高速固体粒子循環速度と均一なガス滞留時間を必 要とする炭化水素熱分解に向いているとしている。こ の装置は，アニュラス部固体粒子は極めて穏やかな流 動状態にあり, 乾燥装置としても優れた特性を発揮す ると考えられる。

ドラフトチューブを付けることで，吹き込みノズル ガスのより多くがドラフトチューブに流入し, かつア ニュラス部ガスと噴流部ガス（ドラフトチューブ内ガ 


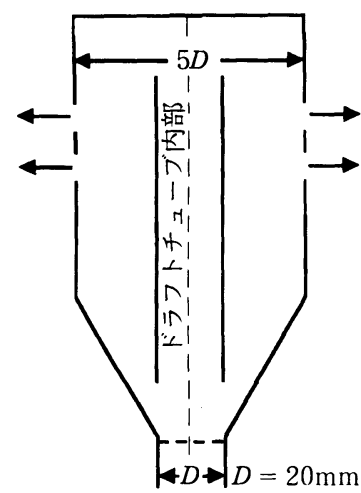

粒子径 $=0.65 \mathrm{~mm}$

図 8 側面出口を持つドラフトチューブ付き噴流層（1

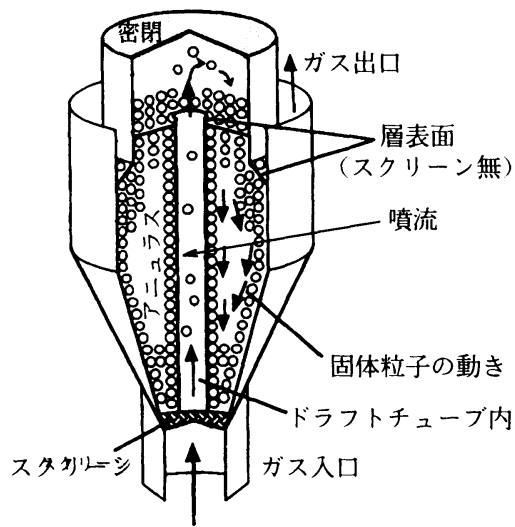

図9側面出口を持つドラフトチューブ付き噴流層（2）

ス）との交換が無くなり乾燥効率が低下することにな る。それを防止するために，ドラフトチューブを多孔 質にすることが必要になった ${ }^{100}$ 。

服部ら ${ }^{11}$ 12) は側壁に排気口を設けた円筒型噴流層 を考案した。これはガス流れの多くの部分が噴流部の みを通過し, 気固接触に問題を残していると考え, 送 入ガスのすべてを環状粒子層を通過させるための工夫 であるが，当然図 8 に示すようにドラフトチューブ付 き噴流層にもこれを適用し，他の装置の場合と同様に ドラフトチューブを付けることで圧力損失の減少を認 め，送入ガスや粒子の滞留時間がより均一になり，ド ラフトチューブを設けない場合に比べて格段に性能が 改善されることを明らかにした。さらに，ガスの排出 方法を図9のように改善することで，ガス出口孔に張 った網への粒子の詰まりを防ぎ，この装置の特性を生 かすことが出来た ${ }^{13.14)}$ 。最近，服部らはこの装置の延 長として, 噴流層が中央部にガス吹き込み口を設置し

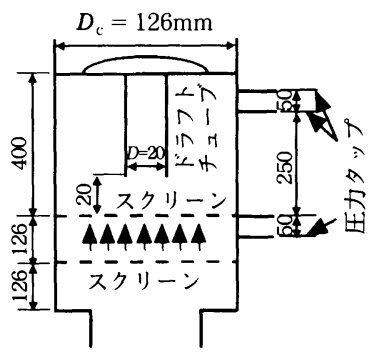

(A) フラットスクリーンを 用いたガス注入

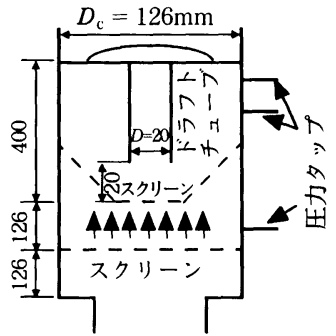

(B) コニカルスクリーンを

図 10 服部らにより新しく提案された ドラフトチューブ付き噴流層

なくてもアニュラス部に十分なガス流速が存在すれば 粒子が安定的に循環するという事実から，図10のよ うな，通常みられるガス吹き込みノズルやオリフィス を取り除き，層底部にスクリーンを設けることで装置 全体を一様なガス速度で通過出来るようにした，ドラ フトチューブ付き噴流層装置を作成した。この装置を 試験した結果, 当然の事ながら，アニュラス部への大 幅なガス流の增加を観測し，且つ压力損失の減少も認 められており, 乾燥装置として今後有望な装置として 注目される ${ }^{15)}$ 。成瀬ら ${ }^{16)}$ の高速流動層と移動層を組み 合わせた CFM 層型固気接触も，ドラフトチューブ付 き噴流層の一種と考えても良いと思われる。

ドラフトチューブ付き噴流層の伝熱特性 Freire $ら^{17)}$ は, $0.51 \mathrm{~m}$ の円筒形噴流層における管壁と層粒 子間の伝熱係数 $h$ (wall to bed heat transfer coefficient）を、コーン部の角度を 30 度から 60 度の 間で変化させて測定した。代表的な結果を図 11 に示 す。 $h$ は粒子径が大きくなるほど大きくなるが, 層 高が高くなるほど減少した。しかし，ガス流速には依 存しないことがわかった。またコーン部の角度を増加 $\left(\theta=30^{\circ} \rightarrow 60^{\circ}\right)$ するほど $h$ は小さくなり, ドラフト チューブを挿入すると $h$ は小さくなることがわかっ た。これは結局，管壁付近の粒子の移動速度が大きい ほど $h$ が大きくなることを示しているものである。 


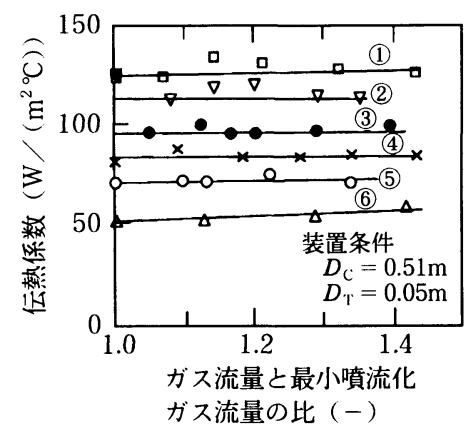

実験条件

\begin{tabular}{c|c|c|c}
\hline 図中の番号 & $\begin{array}{c}\text { 静止層高 } \\
(\mathrm{m})\end{array}$ & $\begin{array}{c}\text { ガラスビーズ } \\
\text { 粒子径 } \\
d_{\mathrm{p}} \times 10^{3} \\
(\mathrm{~m})\end{array}$ & $\begin{array}{c}\text { ドラフトチューブ } \\
\text { の有無 }\end{array}$ \\
\hline (1) & 0.17 & 2.6 & 無 \\
\hline (2) & 0.21 & 2.6 & 無 \\
\hline (3) & 0.26 & 2.6 & 無 \\
\hline (4) & 0.26 & 2.6 & 有 \\
\hline (5) & 0.26 & 1.8 & 有 \\
\hline (6) & 0.26 & 0.9 & 有 \\
\hline
\end{tabular}

図 11 噴流層における粒子の伝熱特性

また，ドラフトチューブを挿入した場合には，ドラフ 卜内とアニュラス部とのガスの交換が無くなったため と，ガス流のより多くの部分がドラフトチューブ内を 流れることによって，アニュラス部のガス流が減少し たために $h$ が小さくなったと考えられる。彼らは最 終的に次式のような相関式を得た。

$$
N_{\mathrm{u}}\left(=h D_{\mathrm{p}} / \gamma\right)=8.4 A r^{0.02}\left(H / D_{\mathrm{p}}\right)^{-1.26}(\cos \theta)^{0.88}
$$

ただし， $A r$ はアルキメデス数で次式で定義される。

$$
A r=g D_{\mathrm{p}}^{3}\left(\rho_{\mathrm{p}}-\rho_{\mathrm{f}}\right) \rho_{\mathrm{f}} / \mu_{\mathrm{f}}^{2}
$$

Barrett ら ${ }^{18)}$ ，Claflin ら ${ }^{19)}$ は，回分加熱方式により 噴流層の総括的伝熱特性を検討した。層内を完全混合 とみなし次式のような熱収支式をたてた。

$$
M C_{\mathrm{ps}} \frac{\mathrm{dT}}{\mathrm{d} t}=m C_{\mathrm{pg}}\left(T_{\mathrm{i}}-T_{\mathrm{e}}\right)-K\left(T_{\mathrm{b}}-T_{\mathrm{a}}\right)
$$

ここで， $T_{\mathrm{b}}, T_{\mathrm{i}}, T_{\mathrm{e}}$ 及び $T_{\mathrm{a}}$ はそれぞれ層，ガス入り 口, ガス出口及び外界の温度, 右辺の $K$ を含む第 2 項は外界への熱損失を表している。接触効率 $\eta\left(=\left(T_{\mathrm{i}}-T_{\mathrm{e}}\right) /\left(T_{\mathrm{i}}-T_{\mathrm{b}}\right)\right)$ を導入し, 時間 $t$ と層温度 $T_{\mathrm{b}}$ との関係を導出し, ドラフトチューブ無しの場合 が接触効率が約 0.8 であったのに対し，ドラフトチ

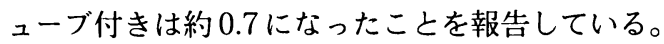

噴流層における流体一粒子間の熱伝達係数について は, Mujumdar ${ }^{4)}$ が指摘しているように, アニュラス 部で $50 \mathrm{~W} /\left(\mathrm{m}^{2} \cdot \mathrm{K}\right)$ のオーダーにあり, 噴流部内では その 8 倍 $\left(400 \mathrm{~W} /\left(\mathrm{m}^{2} \cdot \mathrm{K}\right)\right)$ ぐらいになっている。前 者は充塡層や移動層における伝熱係数, 後者は空気輸 送における伝熱係数と同様に考えることで上述のこと が言える訳であるが, 通常の乾燥ではアニュラス部の 比較的低い伝熱係数と長い滞留時間による伝熱が, 噴 流部の高い伝熱係数を短い滞留時間（<1 秒）による それを上まわると言われている2)。Claflin ら ら $^{10)}$ は噴 流部（ドラフトチューブ）に粒子の（表面温度ではな く）平均温度に基づく伝熱係数 $h_{\mathrm{s}}^{*} （ \fallingdotseq 100 \mathrm{~W} /\left(\mathrm{m}^{2}\right.$. K)）を導入し，アニュラス部をガス熱的平衡にある と仮定することで粒子層高, 流入ガス温度さらにドラ フトチューブ壁のタイプ (porous, non-porous) の層 温度に及ぼす影響についてモデル計算し，概念モデル 計算値が実測值と合致するとしている。

Stocker ら ${ }^{20)}$ は, ドラフトチューブ付き噴流層に 対してアニュラス部, ドラフトチューブ内, ドラフト チューブ上の噴流部の各部で別々の物質及び熱収支式 を立て，また粒子循環速度や伝熱係数等の推算は既存 の相関式を使用することでモデル計算を行った。これ により, 各部のガス及び粒子の温度予測が可能になっ た。モデルシミュレーションによって, 炭化水素の熱 分解のような高速, 競争反応には, ドラフトチューブ 付き噴流層が非常に有効なことが示された。Eng ら は1) はドラフトチューブ付き噴流層の温度特性を知 るため, 定常状態のみならず過渡的状態についても適 用できるモデル化（ダイナミックモデル化）を行っ た。計算值はベンチスケール $\left(D_{\mathrm{c}}=0.11 \mathrm{~m}\right)$ の応答実 験の結果（ドラフトチューブ内ガス温度分布）を良く 説明している。

\section{1. 噴流挙動に関する研究}

ドラフトチューブを挿入することにより，アニュラ ス部からスパウト部への粒子の流れがなくなり，ま た，チューブが非透過性であれば，スパウト部からア ニュラス部へのガス浸透流れもなくなり, 流動状態が 大幅に改善される。ドラフトチューブ付き噴流層操作 の特性は以下のごとく示される ${ }^{1822) 。 ~}$

1）滞留時間を制御できる。

2）連続操作が可能で，流れは栓流を仮定できる。

3）通常の噴流層に比へ，圧力損失や最小噴流化速 度が小さく, 操作上の自由度が大きい。

4）粒子充填層高に制限が無い。 
表 1 主たる噴流因子に関する論文

\begin{tabular}{|c|c|c|c|c|c|c|c|c|}
\hline $\begin{array}{l}\text { 主な } \\
\text { 対象特性 }\end{array}$ & 研究者 & $\begin{array}{l}\text { 文 } \\
\text { 献 }\end{array}$ & $\begin{array}{l}\text { 塔形状, 塔径, } \\
\text { 開角, } \\
\text { ノズル径 }(\mathrm{m})\end{array}$ & $\begin{array}{l}\text { チューブ構造, } \\
\text { チューブ径 }(\mathrm{mm})\end{array}$ & $\begin{array}{l}\text { 使用粒子, } \\
\text { 粒子密度 } \rho_{p} \\
\left(\mathrm{~kg} / \mathrm{m}^{3}\right)\end{array}$ & $\begin{array}{l}\text { 平均粒径 } \\
D_{\mathrm{p}}(\mu \mathrm{m})\end{array}$ & $\begin{array}{l}\text { 空塔速度 } \\
(\mathrm{m} / \mathrm{s})\end{array}$ & 備考 \\
\hline \multirow[t]{5}{*}{$\begin{array}{l}\text { 噴流特性 } \\
\text { 全般 }\end{array}$} & $\begin{array}{l}\text { 石倉ら } \\
1996\end{array}$ & 36 & $\begin{array}{l}\text { 円筒 } \\
0.1 \text {. } \\
60^{\circ} \\
0.012\end{array}$ & $\begin{array}{l}\text { 多孔，千鳥配列 } \\
\text { porous } \\
12,14,18,23\end{array}$ & $\begin{array}{l}\text { ガラスビーズ } \\
2480\end{array}$ & $803-1914$ & $\begin{array}{l}\text { 入口基準 } \\
0.3-1.5\end{array}$ & DSB \\
\hline & $\begin{array}{l}\text { 石倉ら } \\
1994\end{array}$ & 23 & $\begin{array}{l}\text { 円筒 } \\
0.1 \\
0.012 \\
\end{array}$ & $\begin{array}{l}\text { solid } \\
12-23\end{array}$ & $\begin{array}{l}\text { ガラスビーズ } \\
2480\end{array}$ & $803-1914$ & $\begin{array}{l}\text { 入口基準 } \\
0.1-0.7\end{array}$ & DSB \\
\hline & $\begin{array}{l}\text { Claflin } \\
1984\end{array}$ & 10 & $\begin{array}{l}\text { 円筒, 半円筒 } \\
0.3 \\
60^{\circ} \\
0.05\end{array}$ & $\begin{array}{l}\text { solid } \\
60-80 \\
\text { porous } \\
\text { 網メッシュ }(14 \times 24)\end{array}$ & $\begin{array}{l}\text { AS小麦 } \\
1400\end{array}$ & $\begin{array}{l}3,500 \\
(5.5 \times 3.2)\end{array}$ & $\begin{array}{l}\text { 入口基準 } \\
15.3-38.3\end{array}$ & DSB \\
\hline & $\begin{array}{l}\text { Yang \& } \\
\text { Keairns } \\
1983\end{array}$ & 29 & $\begin{array}{l}\text { 半円筒 } \\
0.286 \\
60.90\end{array}$ & $\begin{array}{l}0.0955 \mathrm{~m} \\
\text { solid }\end{array}$ & $\begin{array}{l}\text { ポリエチレンビーズ } \\
910 \\
\text { エポキシ球 } \\
210\end{array}$ & $\begin{array}{l}2800 \\
2800\end{array}$ & $\begin{array}{l}1-4.3 \\
{[\mathrm{SCMM}]}\end{array}$ & DSB \\
\hline & $\begin{array}{l}\text { Buchanan } \\
\text { et al. } \\
1965\end{array}$ & 22 & $\begin{array}{l}\text { 円筒 } \\
0.15,0.076 \\
60 \mathrm{deg} \\
0.007,0.013 \text {, } \\
0.022 \\
\end{array}$ & $\begin{array}{l}\text { solid } \\
15,37,70\end{array}$ & $\begin{array}{l}\text { 小麦, } \\
\text { 菜種種子 } \\
\text { 陟リンン゙ーズ, } \\
\text { PVC }\end{array}$ & $\begin{array}{l}\text { 微粉から } \\
20 \mathrm{~mm} \text { 程度 }\end{array}$ & $\begin{array}{l}0.39-2.94 \\
{[1 \mathrm{~b} / \mathrm{min}]}\end{array}$ & DSB \\
\hline $\begin{array}{l}\text { 噴流化曲線 } \\
\text { 帯留時間 }\end{array}$ & $\begin{array}{l}\text { S. J. Kim } \\
1990\end{array}$ & 14 & $\begin{array}{l}\text { 半円筒 } \\
0.128 \\
180 \mathrm{deg} \\
0.0186\end{array}$ & $\begin{array}{l}\text { solid } \\
21\end{array}$ & $\begin{array}{l}\text { ガラスビーズ } \\
2460 \\
2400 \\
2840 \\
\end{array}$ & $\begin{array}{l}540 \\
850 \\
1390\end{array}$ & $\begin{array}{l}\text { 入口基準 } \\
0.02-0.8\end{array}$ & DSB \\
\hline $\begin{array}{l}\text { 圧損分布 } \\
\text { 帯留時間 }\end{array}$ & $\begin{array}{l}\text { Mathew } \\
\text { et al. }\end{array}$ & 32 & \begin{tabular}{l|} 
半円筒 \\
0.152 \\
$180 \mathrm{deg}$ \\
$0.010-0.0254$ \\
\end{tabular} & $\begin{array}{l}\text { solid } \\
28.6 \\
44.5\end{array}$ & $\begin{array}{l}\text { ガラスビーズ } \\
2490 \\
2580 \\
2890 \\
\end{array}$ & $\begin{array}{l}462 \\
180 \\
1300 \\
\end{array}$ & $\begin{array}{l}0-0.23 \times 10^{-3} \\
\left(\mathrm{~m}^{3} / \mathrm{s}\right)\end{array}$ & $\begin{array}{l}\mathrm{DSB} \\
\text { 固液系 }\end{array}$ \\
\hline $\begin{array}{l}\text { 压損分布 } \\
\text { 粒子循環量 }\end{array}$ & $\begin{array}{l}\text { Law et al. } \\
1986\end{array}$ & 5 & $\begin{array}{l}\text { 2次元 } \\
20.2 \\
180 \mathrm{deg} \\
0.01,0.03\end{array}$ & $\begin{array}{l}\text { solid } \\
35,65\end{array}$ & $\begin{array}{l}\text { 大麦 } \\
\text { トウモロコシ } \\
\text { エンドウ豆 } \\
\text { 小麦 }\end{array}$ & $\begin{array}{l}\text { bulk } \\
612,715 \\
684,719\end{array}$ & $\begin{array}{l}\text { 塔基準, } \\
0.5-3.2\end{array}$ & DSB \\
\hline $\begin{array}{l}\text { 噴流化曲線 } \\
\text { 最小安定噴流 } \\
\text { 化速度 }\end{array}$ & $\begin{array}{l}\text { 伊地知ら } \\
1988\end{array}$ & 24 & $\begin{array}{l}\text { 円筒 } \\
0.05 \\
60 \mathrm{deg} \\
0.01 \\
\end{array}$ & $\begin{array}{l}\text { solid } \\
8,10,14\end{array}$ & $\begin{array}{l}\text { ガラスビーズ } \\
2500\end{array}$ & $\begin{array}{l}950,1670 \\
2360,3210\end{array}$ & $\begin{array}{l}\text { 入口基準 } \\
1-17\end{array}$ & DSB \\
\hline $\begin{array}{l}\text { 最小噴流化速 } \\
\text { 度 } \\
\text { スケール効果 }\end{array}$ & $\begin{array}{l}\text { 服部ら } \\
1981\end{array}$ & 26 & $\begin{array}{l}\text { 円筒 } \\
0.1,0.15,0.2 \\
60 \mathrm{deg} \\
0.2 \mathrm{D}\end{array}$ & $\begin{array}{l}\text { solid } \\
20,30,40\end{array}$ & $\begin{array}{l}\text { ガラスビーズ } \\
2500\end{array}$ & $270-1800$ & $\begin{array}{l}\text { 入口基準 } \\
7.3-8.3\end{array}$ & DSB \\
\hline $\begin{array}{l}\text { 最小噴流化速 } \\
\text { 度 }\end{array}$ & $\begin{array}{l}\text { Barrett } \\
\text { et al. } \\
1983\end{array}$ & 18 & $\begin{array}{l}\text { 円筒 } \\
0.3 \\
\overline{0.05} \\
\end{array}$ & $\begin{array}{l}\text { solid } \\
0.05\end{array}$ & $\begin{array}{l}\text { 小麦 } \\
\text { Celcon }\end{array}$ & $\begin{array}{l}3500 \\
2500\end{array}$ & $\begin{array}{l}\text { 安定域から } \\
\text { 录ーキン } \\
\text { グ迄 }\end{array}$ & DSB \\
\hline $\begin{array}{l}\text { アニュラスガ } \\
\text { ス流量 } \\
\text { 粒子循環量 }\end{array}$ & $\begin{array}{l}\text { Milne et al. } \\
1992\end{array}$ & 9 & $\begin{array}{l}\text { 半以筒 } \\
0.2 \\
60 \mathrm{deg} \\
0.026 \\
\end{array}$ & $\begin{array}{l}31,44 \\
\text { 小癿: } 6.25,8.25 . \\
11.1\end{array}$ & $\begin{array}{l}\text { 珪砂 } \\
2630 \\
\text { ポリエチレンビーズ } \\
1200 \\
\end{array}$ & \begin{tabular}{l|}
610 \\
1310 \\
1280 \\
\end{tabular} & $\begin{array}{l}\text { 入口基準 } \\
2.41(1 / \mathrm{s}) \\
9.13(1 / \mathrm{s})\end{array}$ & DSFB \\
\hline $\begin{array}{l}\text { アニュラスガ } \\
\text { ス流量 } \\
\text { 多孔管モデル }\end{array}$ & $\begin{array}{l}\text { Claflin et al. } \\
1983\end{array}$ & 31 & \begin{tabular}{|l|} 
円筒，半円筒 \\
0.3 \\
$60^{\circ}$ \\
0.05 \\
\end{tabular} & $\begin{array}{l}\text { solid } \\
50-80 \\
\text { porous } \\
\text { 網メッシュ }(14 \times 24) \\
\end{array}$ & $\begin{array}{l}\text { AS小麦 } \\
1400\end{array}$ & $\begin{array}{l}3,500 \\
(5.5 \times 3.2)\end{array}$ & $\begin{array}{l}\text { 入口基準 } \\
15.3-38.3\end{array}$ & $\begin{array}{l}\text { annular } \\
\text { gas flow } \\
\text { separation } \\
\text { distance } \\
\end{array}$ \\
\hline 粒子循環量 & $\begin{array}{l}\text { Kalwar et al. } \\
1993\end{array}$ & 7 & \begin{tabular}{|l|}
2 次元 \\
$0.75,0.50$ \\
$45^{\circ}$ \\
$60^{\circ}$ \\
0.333 \\
0.05 \\
\end{tabular} & $\begin{array}{l}\text { solid } \\
50,75,100\end{array}$ & $\begin{array}{l}\text { トウモロコシ } \\
732 \\
\text { 大豆 } \\
756 \\
\text { 小麦 } \\
765 \\
\end{array}$ & $\begin{array}{l}8050 \\
6630 \\
3630\end{array}$ & 記載なし & DSB \\
\hline $\begin{array}{l}\text { 粒子循環量 } \\
\text { アニュラスガ } \\
\text { ス流量 }\end{array}$ & $\begin{array}{l}\text { Muir et al. } \\
1990\end{array}$ & 33 & \begin{tabular}{|l|} 
半円筒 \\
0.2 \\
$60^{\circ}$ \\
0.027 \\
\end{tabular} & $\begin{array}{l}\text { solid } \\
23,40\end{array}$ & $\begin{array}{l}\text { 珪砂 } \\
2560\end{array}$ & 1020 & $\begin{array}{l}\text { 入口基準 } \\
13-45\end{array}$ & $\begin{array}{l}\text { DSB } \\
\text { DSFB }\end{array}$ \\
\hline $\begin{array}{l}\text { 粒子循環量 } \\
\text { 粒子ホールド } \\
\text { アップ }\end{array}$ & $\begin{array}{l}\text { 伊地知ら } \\
1990\end{array}$ & 28 & $\begin{array}{l}\text { 円筒 } \\
0.05 \\
60^{\circ} \\
0.01 \\
\end{array}$ & $\begin{array}{l}\text { solid } \\
11.4,18.0\end{array}$ & $\begin{array}{l}\text { 鉄粉 } \\
7660\end{array}$ & 205 & $\begin{array}{l}0-0.003 \\
\left(\mathrm{~m}^{3} / \mathrm{s}\right)\end{array}$ & DSB \\
\hline $\begin{array}{l}\text { 実験結果とモ } \\
\text { デル計算との } \\
\text { 比較 }\end{array}$ & $\begin{array}{l}\text { Claflin et al. } \\
1982\end{array}$ & 30 & $\begin{array}{l}\text { 円筒, 半円筒 } \\
0.3 \\
60 \mathrm{deg} \\
0.058 \\
0.076\end{array}$ & $\begin{array}{l}\text { solid } \\
\text { porous } \\
58-76\end{array}$ & $\begin{array}{l}\text { 小麦 } \\
1350 \\
1400\end{array}$ & $\begin{array}{l}3700 \\
3500\end{array}$ & $\begin{array}{l}0-0.108 \\
\left(\mathrm{~m}^{3} / \mathrm{s}\right)\end{array}$ & DSB \\
\hline
\end{tabular}


5）通常の噴流層よりスケールアップが容易である。 しかし, ドラフトチューブを挿入することにより， 通常の噴流層に比べ，操作因子が増加した上に新たに ドラフトチューブの閉塞の危険性も生じてくる。した がって, 安定的に本装置を操作するためにはその流動 特性を的確に把握しておく必要がある。

本章では, ドラフトチューブ付き噴流層の各パラ メータに関する研究について概観する。また, 噴流挙 動の実験に関する論文を表 1 にまとめて示した。

\section{1 噴流特性}

一般に反応装置は透明ではないので外部からの観察 が困難である。供給ガス流量と圧力損失との関係を示 す流動特性曲線を把握しておけば，装置内の流動状態 が予測できる。ドラフトチューブ付き噴流層の流動特 性曲線に関しては Buchanan ら ${ }^{22)}$ に始まって, 多く の研究者 ${ }^{14}$ 23 25) によって測定されている。石倉ら ${ }^{23)}$ の塔压力損失と入口ガス速度との関係, およびチュー ブ内压力損失と入口ガス速度との関係の測定結果を図 12,13 に示す。塔圧力損失およびチューブ圧力損失

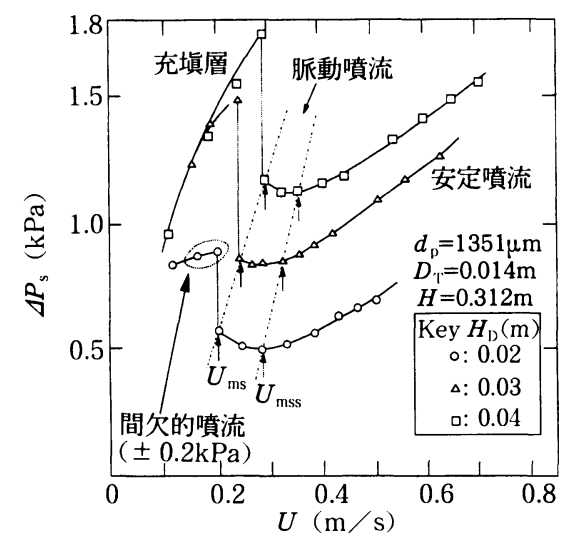

図12 塔圧損と入口ガス量の関係

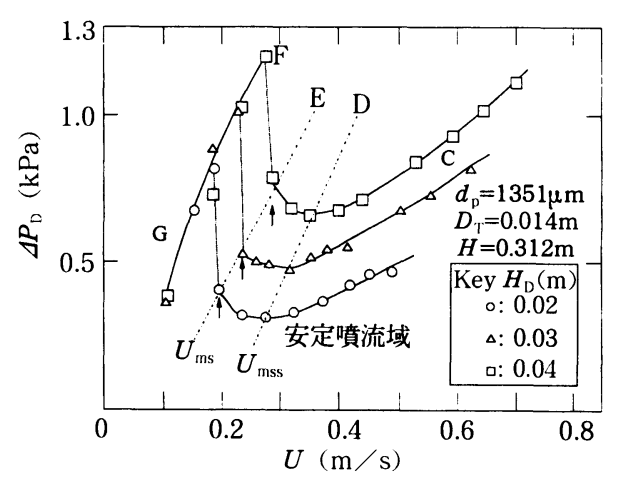

図13チューブ压損と入口ガス量の関係
と入口ガス流速との関係は，その圧力損失の大きさは 異なるが似たような挙動を示しており，層の挙動はチ ューブ内の粒子挙動に依存していることが示されてい る。通常の噴流層（ドラフトチューブ無し）の場合 は，最小噴流化速度以上のガス速度では実質的には一 定の圧力損失を示すが, ドラフトチューブ付き噴流層 の場合は，チューブの圧力損失が付加され，ガス速度 の増加とともに増加傾向を示す ${ }^{2224)}$ 。 ガス速度を増加 させて噴流化実験を行うと，ガス量が小さい領域では チューブの閉塞が生じる。Buchanan ら ${ }^{22)}$ の場合, チ ューブ閉塞をガス圧で除去するのに安定噴流時の 10 倍以上の圧力損失が必要となっている。したがって, 測定は十分なガス量で完全噴流状態を形成させたのち ガス量を徐々に減少させて行われている。一般にドラ フトチューブ付き噴流層の最小噴流化速度 $U_{\mathrm{ms}}$ は, 定常噴流からガス流量を減少させたとき，噴流が停止 し，固定層状態に戻るときのガス速度として定義され ている。しかしながら，噴流状態はスパウト部の粒子 が輸送された後形成されるので, $U_{\mathrm{ms}}$ は粒子物性, 噴 流化ガスの物性および層の形状に依存することにな る。Barrett ら ${ }^{18)}$ は，小麦を流動化粒子として用いた 実験で, 通常の噴流層とドラフトチューブ付き噴流層 での最小噴流化速度を測定し，ドラフトチューブ付き 噴流層の場合，スパウト部からアニュラス部へのガス 浸透流れが無くなるため, 最小噴流化速度が小さくな ることを示している。実験結果を図 14 に示す。ま た，図中には，塔圧損と充填層高の関係も示されてお り，ドラフトチューブ付き噴流層の場合は，チューブ

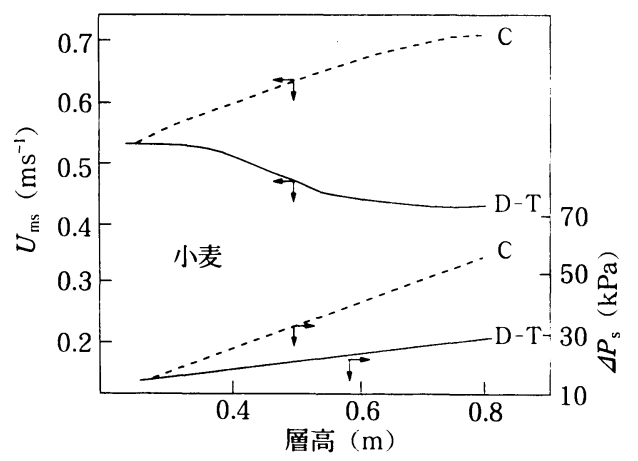

（C：通常噴流層, D-T：ドラフトチューブ付き噴 流層 (ソリッドチューブ, チューブ間距離 $=0.15 \mathrm{~m}$, チューブ径 $=0.05 \mathrm{~m}$, チューブ長 $=1.3 \mathrm{~m})$ )

図14 最小噴流化速度および塔圧損に対する 通常噴流層とドラフトチューブ付き噴 流層との比較 
を挿入することにより，スパウトからアニュラスへの ガス流れがないために塔压損が小さくなっていること がわかる。服部ら ${ }^{26)}$ (1981）は，スパウト部の固気接 触効率を改善するための側方排気型の装置を用い，石 倉ら ${ }^{23)}$ は円筒型の装置を用いて $U_{\mathrm{ms}}$ を測定し，それ ぞれ $U_{\mathrm{ms}}$ は流動粒子の終末速度の $80,70 \%$ のガス速 度で与えられるとしている。また．定常噴流からガス 流量を減少させたときの圧力損失曲線の極小値を, 最 小安定噴流化速度 $U_{\mathrm{mss}}$ として定義する提案もみられ る ${ }^{24)}$ 。 $U_{\text {mss }}$ を過ぎてガス速度を小さくしていくと, 粒子ホールドアップが増加しチューブ閉塞へとつなが るが，この領域では $U_{\mathrm{mss}}$ から $U_{\mathrm{ms}}$ までの短区間なが ら粒子ホールドアップが高く, 良好な固気接触効率が 期待できるという特性があり，装置特性を知るために はこの特性を的確に把握する必要がある。 $\mathrm{Kim}^{14)}$ と Law-Kwet-Cheong ら5)（1986）は，それぞれ半円 筒型でファウンティン部に内筒を取り付けた装置およ び二次元型, 変形二次元型の装置を用い，噴流域から 固定層領域までの圧力損失と空塔速度との関係を示し ているが, 装置形状の複雑さに比例してその挙動も複 雑になることが示されている。

Grbavcic ら ${ }^{27)}$ は, 液系のドラフトチューブ付き噴 流流動層に対して, 最小噴流流動化速度, 軸方向圧力 損失，アニュラス部液速度，粒子循環量などの噴流化 特性値の実験值とモデル計算の結果との比較を行って いる。Kalwar ら ${ }^{6)}$ は，スケールアップの容易さから 二次元型のドラフトチューブ付き噴流層を用いて，そ の圧力損失曲線や最小噴流化速度およびその実験式を 得ている。

\section{2 アニュラス部ガス流量}

ドラフトチューブ付き噴流層におけるバイパス流 量, すなわちアニュラス部ガス流量は，流動粒子や流 動化ガスの滞留時間や粒子循環量に大きく影響を及ぼ すので，その特性を把握するために多くの研究者によ

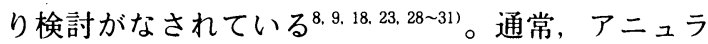
ス部ガス流量は，アニュラス部の粒子下降速度がガス 速に比べて小さいことから固定層を仮定して，ア二ュ ラス部の圧力損失からガス流速を予測する手法が取ら

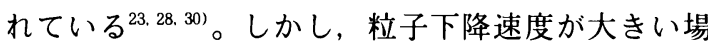
合，その分を補正する必要があり，さらにアニュラス 部が流動化する場合にはこの方法は使えない。アニュ ラス部ガス流量は塔とチューブの塔径比, チューブと 入口ノズル径の比, チューブ間距離, 使用粒子, 充填 量, 入口ガス流量等の設計因子や操作因子に大きく影

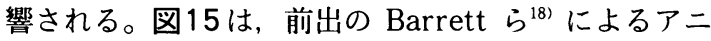

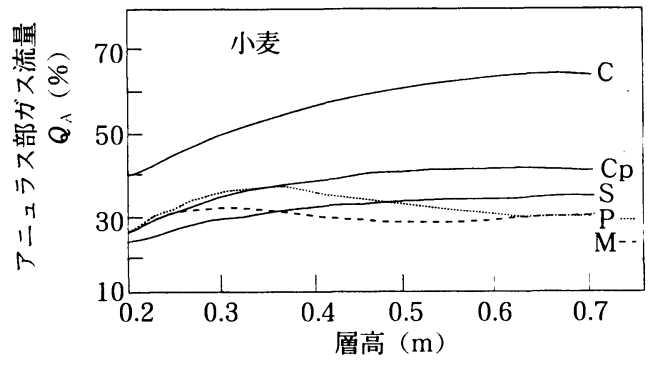

(C：通常噴流層, $\boldsymbol{Q}_{\uparrow}=0.05 \mathrm{~m}^{3} / \mathrm{s} ; \mathrm{Cp}$ : 合成チューブ $(0.3 \mathrm{~m}$ porous $+0.5 \mathrm{~m}$ solid $), Q_{\uparrow}=0.03 ; \mathrm{S}:$ ソリッド チューブ, $\mathrm{P}:$ 多孔チューブ, $\mathrm{M}:$ モデ, $\left.Q_{\uparrow}=0.035\right)$

図15層高とアニュラス部ガス流量との関係

ュラス部流量比と充塡層高の関係を示したものであ る。通常のチューブと多孔質チューブとを比較する と, 充填層高が高い領域では, アニュラスからスパウ トへのガスの逆流が生じている現象が示唆されてい る。したがって，多孔チューブの場合，スパウトから アニュラスへのガス浸透流れを注意深く考慮する必要 がある ${ }^{8)}$ 。多孔質チューブは，ガスの滞留時間を増す ためにチューブ間距離を小さくとる場合においても， 処理量を増すために全ガス量を大きくとった場合にお いても，通常のチューブに比べ有利であるとしてい る ${ }^{31}$ 。アニュラス部にエアレーションを行う噴流流動 層型の場合，噴流用とエアレーション用の二つのガス 流れがあるので，エアレーション用ガスの吹込み量に より, 層全体の挙動が通常の場合とは全く異なり複雑 になる29)。スパウトからアニュラスへのバイパスガス 量の検討には，トレーサー法が有効となる。Claflin $ら^{31)}$ は, 塔径 $0.3 \mathrm{~m}$ の噴流層で, 円筒と半円筒，更 に，多孔質のドラフトチューブと通常のチューブを取 り付けて幅広く噴流化実験を行っている。図16，17 は Claflin らが，半円筒で多孔質チューブを用い，正 面に配列された圧力タップからの压損データから得ら れた，アニュラスガス流れの速度ベクトル図と高さ方 向のアニュラス部流量比率である。多孔質チューブの 場合, 軸方向圧力損失分布のために，アニュラス部下 部では速度べクトルがチューブ方向を向いており，こ の付近に流量の最大值があることが示されている。さ らに，スパウト部に垂直方向希薄輸送層，アニュラス 部に移動層を仮定したモデル計算からもこの特性の存 在が示されている。 Matthew ら ${ }^{322}$ は，ドラフトチ ューブ付き噴流層の環状部内の流動特性を記述するの に, 二次元の Darcy \& Ergun モデルを用いて, 液系 の噴流に対し, 圧力と流れ関数の実験データと推算值 


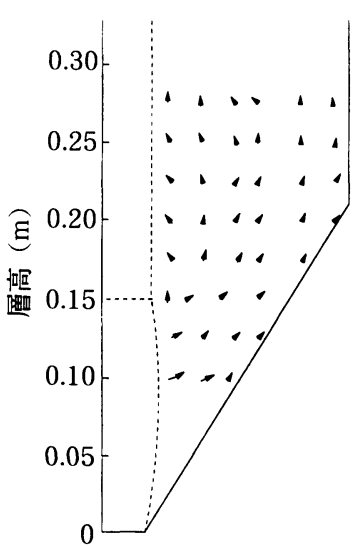

(多孔チュープ, $1 / 2$ bed, $Q_{\text {川 }}=0.024 \mathrm{~m}^{3} / \mathrm{s}$, $\left.L_{\mathrm{D}}=0.8 \mathrm{~m}, H_{\mathrm{D}}=0.15, H_{\mathrm{m}}=0.8\right)$

図 16 各層高におけるアニュラス部 のガス速度ベクトル

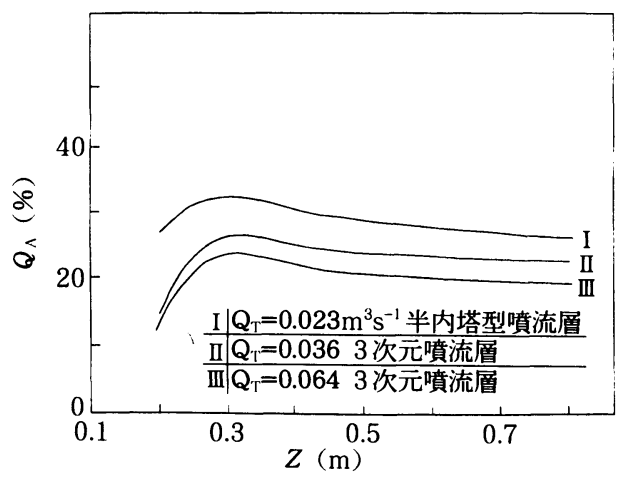

(多孔チュープ, $L_{\mathrm{D}}=0.8 \mathrm{~m}, H_{\mathrm{D}}=0.15, H_{\mathrm{m}}=0.8$ ， $D_{\mathrm{T}}=0.058$ )

図17アニュラス部流量比に及ぼす層高と 全ガス流量の影響

は良く一致することを示している。図18に石倉ら ${ }^{23)}$ の, 入口ガス流量とアニュラスガス流量比との関係の 測定結果を示す。アニュラス部ガス流量比は, 入口ガ ス速度の減少とともに減少するが，アニュラス部ガス 流速は, 入口ガス速度の減少とともに減少し, 極小値 をとったのち最小噴流化速度まで增加する ${ }^{23.24) 。 ま ~}$ た,アニュラス部ガス流量は, チューブ間距離, 充填 粒子径を増すと増加し, 粒子充填量, チューブ径を増 すと減少する。アニュラスガス流量に及ぼす層形状や 入口流量の影響を更に明確にするためには, 流体力学 を基にした環状部へのバイパス流れの研究が必要とな る。

\section{3 粒子循環量}

ドラフトチューブ付き噴流層を反応装置として利用

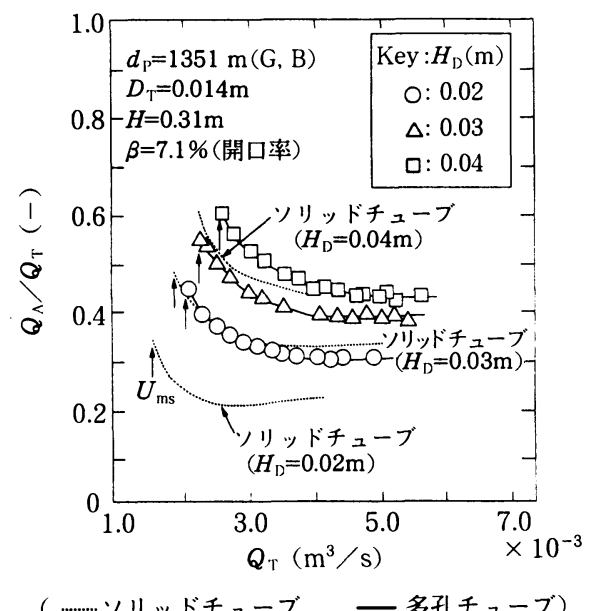

図 18 アニュラス部流量比と入口ガス流量との関係

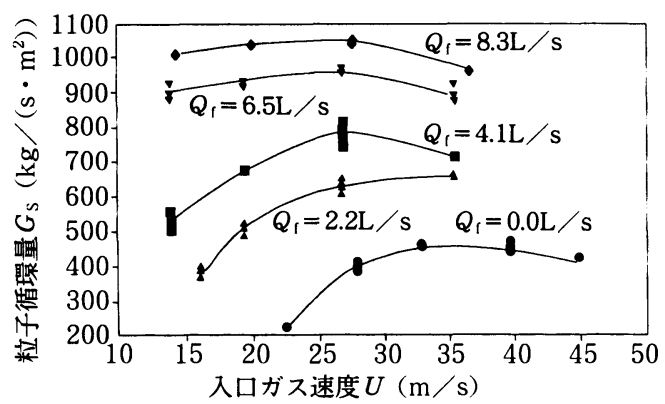

図 19 粒子循環量と入口ガス速度との関係 に及ぼす補助ガス流量の影響

する場合，粒子循環量を確実に制御しなければ高効 率・高収率は望めない。ドラフトチューブ付き噴流層 では，アニュラスからエントレインメントゾーンに供 給された粒子はすべてスパウト部，すなわちチューブ 内を輸送されるので, 粒子循環量はアニュラス部から の粒子供給量と等しい。また，アニュラス部の粒子挙 動はエントレインメントゾーンでのガスの挙動に大き く影響される。粒子循環量を簡単に測定する方法とし ては, 粒子速度, そこでの粒子ホールドアップ, 粒子 密度から計算により求める方法7. ${ }^{79}$, 循環粒子群の衝 撃力から求める方法 ${ }^{28)}$, 粒子の流路を瞬間的に変更し, 一定時間サンプリングの後秤量して求める方法 ${ }^{25)}$ どが考えられる。粒子循環量に影響を与える重要な因 子としては, チューブ間距離, 入口ガス量, 粒子充填 量などが考えられる。Muir ら ${ }^{33)}$ は, 半円筒型の実験 結果を基に，ドラフトチューブ付き噴流層およびドラ フトチューブ付き噴流流動層の粒子循環量に関しての 
詳細な検討結果を示している。粒子循環量の測定結果 の一例を図19に示す。図より，入口ガス量の増加に 対し, 粒子循環量は極大值をとった後減少することが 示されている。これは, 入口ガス量を増すと, アニュ ラスガス流量も増加し，アニュラスからの粒子排出が 制御されるためと考えられ, 石倉ら ${ }^{23)}$, 伊地知ら ${ }^{28)} に$ よる論文でも同様の結果が得られている。

Kalwar ら) (1993) は, 二次元型のドラフトチュー ブ付き噴流層の場合, 円筒型の場合に比べて層底部の 形状の影響を受けやすいとして, 形状の影響を検討す るために噴流化実験を行っている。その結果, 層底部 の開角 $\theta$ が粒子循環時間に影響を与えることを示し, また, 粒子循環量の推算式を次元解析から得ている。

また， Milne ら9) (1992）は，アニュラス部を通る ガスはスパウト部を流れるガスより滞留時間が大き く，これが操作条件やプロセスの効率に大きく影響を 与えるとして, ドラフトチューブにオリフィスを設け てアニュラス部に補助ガスを送入する方式 (ICFB)を 用いて, ガスバイパスの除去を試みている。その結果 として, ICFBは入口ガスとは独立に補助ガスにより 粒子循環量を設定でき，ガスの滞留時間を正確に制御 できることを示している。

高温の場合については, 粒子循環量は基礎的な層お よび粒子・流体系の物理的パラメー夕を基にした既存 の相関式では推算できないことが予想される。さら に, 噴流層における粒子循環量の形状や, 層の物理的 パラメータの依存性を明らかにするためには, 鉛直方 向ガスジェットによる粒子同伴のメカニズムを解明す る必要があると思われる。

\section{4 チューブ内粒子のホールドアップ}

Khoe ら ${ }^{34)}$ は, ドラフトチューブ付き噴流層装置を 小麦の乾燥に利用し，チューブ内の粒子ホールドアッ プが乾燥性能に大きく影響を与えることを指摘してい る。また，チューブの閉塞を避けながら固気接触効率 を高めるため, ホールドアップの高い状態で安定に操 作するためには, チューブ内粒子の挙動を把握してお く必要がある。チューブ内の粒子は, エントレインメ ントゾーンに取り込まれた時点で, 上昇速度ゼロの状 態からある速度まで加速され, 更にファウンティンで 速度ゼロから下向き流れに移行する。以上の区間は非 定常区間であるが, 安定噴流域でのチューブ内の固気 流れは希薄輸送層と考えられている。チューブ内のガ ス速度を減少させていくとチューブ内粒子ホールドア ップは増加し, 間歇噴流からチューブ閉塞に至る。装 置の複雑さのため, チューブ内粒子ホールドアップの

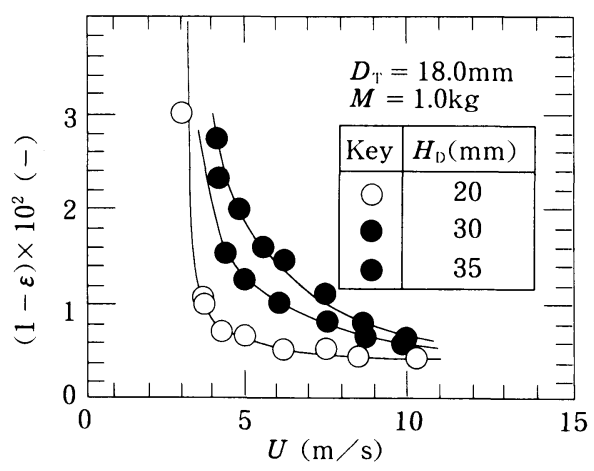

図20粒子ホールドアップとチューブ内 ガス速度との関係

測定データは少ない。成瀬ら ${ }^{35)}$ は CFM 層型固気接触 装置を提案し, そのチューブ内の粒子ホールドアップ をチューブ内粒子平均速度から算出している。通常

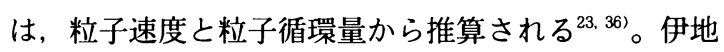
知ら ${ }^{28)}$ (1990) は流動粒子として研磨用の磁性鉄粉を 用い, チューブ内の粒子ホールドアップをインダクタ ンス法を用いて測定している。測定結果の一例を図 20 に示す。チューブ内に粒子下降流が無く, 粒子 ホールドアップがチューブ内のガス速度にほとんど影 響されない希薄輸送層状態と, 粒子下降流が存在し, 粒子ホールドアップがチューブ内ガス速度に大きく影 響される濃厚輸送層状態があることを示している。さ らに, 粒子ホールドアップは, チューブ間距離, 粒子 充填量を増すとともに増加し, 入口ガス速度を増すと 減少することを示している。

\section{5 滞留時間}

通常の噴流層は，アニュラス部のあらゆる位置から スパウト内へ粒子が同伴されるため, 循環粒子の滞留 時間が一定でなく，本質的に連続操作には使い難い が, ドラフトチューブ付き噴流層の場合は, 塔底部の エントレインメントゾーン以外に粒子同伴区間はな く, また, 栓流が仮定できるので, 連続操作に使用可 能と考えられる。滞留時間には，アニュラス部に対し て粒子とガス，そして，スパウト部に対して粒子とガ スの 4つが考えられる。Stocker ら ${ }^{20)}$ は, ドラフト チューブ付き噴流層反応装置を, スパウト部、アニュ ラス部, ファウンティン部に分けてモデル化してい る。シミュレーションの結果として, チューブ内のガ スの滞留時間が $30 \mathrm{~ms}$ 以下で, 高速熱分解に適した反 応装置であることを示している。また, 固気接触効率 を高めるために，スパウト部を出るガスをアニュラス 部に戻すような装置でのアニュラス部のガスと粒子の 
表 2 入口ガス量および設計因子の増加に対する操作因子の傾向

\begin{tabular}{|c|c|c|c|c|c|}
\hline 設計因子 & 操作因子 & $\begin{array}{l}\text { アニュラス部 } \\
\text { ガス流量 }\end{array}$ & 粒子循環量 & $\begin{array}{l}\text { チューブ内粒子 } \\
\text { ホールドアップ }\end{array}$ & $\begin{array}{c}\text { ガス滞留時間 } \\
\text { チューブ内 } \\
\text { アニュラス部 }\end{array}$ \\
\hline 入口ガス量 & 増加 & 減少後増加傾向 & 増加後减少 & 減少傾向 & $\begin{array}{l}\text { 減少傾向 } \\
\text { 减少傾向 }\end{array}$ \\
\hline チューブ間距 & 巨離 增加 & 増加傾向 & 増加傾向 & 増加傾向 & $\begin{array}{l}\text { 増加傾向 } \\
\text { 减少傾向 }\end{array}$ \\
\hline 流動粒子径 & 増加 & 増加傾向 & 増加傾向 & 減少傾向 & $\begin{array}{l}\text { 増加傾向 } \\
\text { 减少傾向 }\end{array}$ \\
\hline 粒子充坥量 & 増加 & 減少傾向 & 増加傾向 & 増加傾向 & $\begin{array}{l}\text { 減少傾向 } \\
\text { 増加傾向 }\end{array}$ \\
\hline
\end{tabular}

滞留時間を測定している ${ }^{14)}$ 。ガスも粒子も流線が複雑 になり，通常のドラフトチューブ付き噴流層に比べて 滞留時間は長くかつ分布は広くなっている。 Claflin ${ }^{30.31)}$ は, エントレインメント部のスパウト径 はチューブ径と等しいと仮定して，スパウト部に空気 輸送モデル，アニュラス部に充填移動層を仮定したモ デル計算を行い, 各部の滞留時間を求めている。モデ ル計算の結果として, ドラフトチューブ付き噴流層 は, 粒子挙動の制御と高い固気接触効率を必要とする 操作に適しているとしている。

噴流挙動のまとめとして, 入口ガス量, チューブ間 距離などに及ぼす設計因子を増加した場合の傾向を表 に纏めると表 2 の如くなるようである。

\section{2. 応用に関する研究}

本章においては，ドラフトチューブ付き噴流層の各 種プロセスへの応用を, 最近の研究についてまとめ

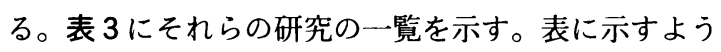
に，大きく非反応と反応に分類できる。非反応には乾 燥, コーティング, 混合及び輸送があり, 反応には石 炭ガス化・燃焼, 都市ゴミ燃焼, 炭化水素熱分解及び 二酸化硫黄の酸化があった。以下, 個別に解説する。

表 3 中のガス線速度について少々補足を行う。第一 に，各々のガス線速度の值は標準状態での值である。 乾燥 $\left(100 \sim 150^{\circ} \mathrm{C}\right)$ やコールドモデル実験 (室温) で は, 実際の線速度とほとんど変わらない。一方, 石炭 ガス化・燃焼, 都市ゴミ燃焼, 炭化水素の熱分解及び 二酸化硫黄の酸化では, 操作温度は大ざっぱに言って $1000 \mathrm{~K}$ であるので, 表中の值を 3 倍すれば実際の線 速度に近い值が得られる。第二に, 論文によってはド ラフトチューブと環状部へのガスの分離比が記載され ていないものがあったので, それらについては, 丁度
半分づつに別れると仮定して, 各部の線速度を算出し た。

\section{1 非反応}

\section{1.1 乾 燥}

Mathur らが 1955 年に発表した最初の噴流層に関 する論文"，および Buchanan らが 1965年に発表し た最初のドラフトチューブ付き噴流層に関する論文 ${ }^{22}$ のいずれにおいても，すでに乾燥への応用についての 記述がある。このように乾燥は最も古くから噴流層の 応用分野であり続けてきた結果, 乾燥に関しては一分 野では最高の 6 つの報告5. 19.34.37 39) がなされている。 乾燥に関するこれらの論文が, 乾燥すべき物質として 特定しているものは, 熱変性を受けやすい物質, 大別 すると小麦をはじめとする穀類5. 19. 34. 37. 39) 及び食品眯 濁液38) である。

第一の含湿穀類の乾燥は, 穀類粒子を空気により循 環させつつ乾燥させるというものである。100から $160^{\circ} \mathrm{C}$ 程度の加熱空気を装置底部から送り込んで, 含 水率 20 から $30 \%$ の穀類粒子をドラフトチューブ付き 噴流層内を循環させ, 含水率 $10 \%$ 程度まで減らすの が通常の操作のようである。Colley ら ${ }^{37)}$ は, 対流加 熱と高周波加熱との比較を行った。Law-KwetCheong ら5) は, 環状部層高及びチューブ間距離が厌 力損失, 循環開始ガス速度及び固体循環速度に及ぼす 影響を検討した。Claflin ら ${ }^{19)}$ は, ドラフトチューブ の有無により流動特性及び乾燥性能がどのように変わ るかを検討した。Khoeら ${ }^{34)}$ は, 主としてチューブ間 距離を変えて籾款つき米粒の乾燥実験を行い, 乾燥操 作中の熱及び物質移動について考察した。米粒は, ド ラフトチューブ内を上昇中にバルクガスから熱を外表 面近傍に受け取り，環状部を下降する間に自己の内部 の温度及び含水率分布を均一化する。したがって, 通 
ドラフトチューブ付き噴流層の応用に関する研究の一覧表

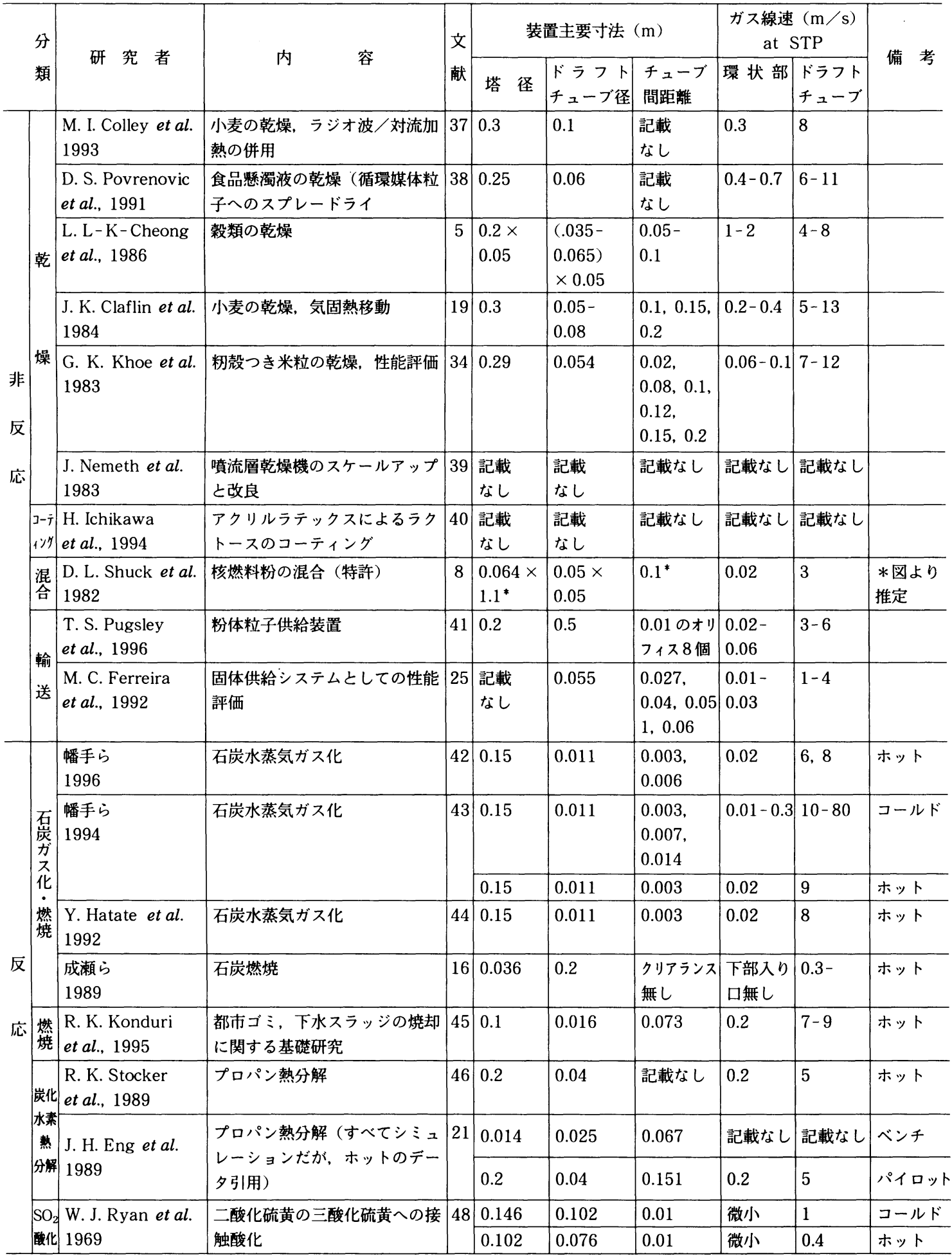




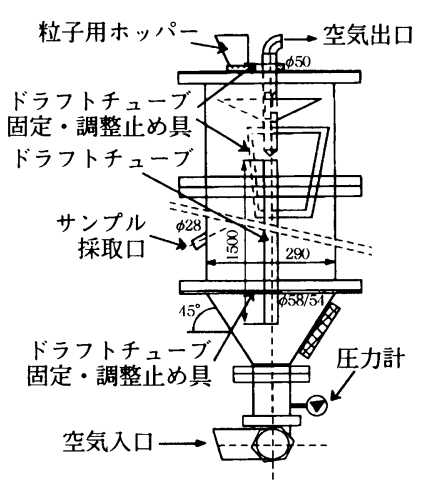

図21 ドラフトチューブ付き噴流層実験装置図

常の噴流層より高い環状部層高をとることができるド ラフトチューブ付き噴流層は，このような熱に敏感な 含水物質の乾燥に適していると結論づけられた。図 21 に彼らが使用した実験装置を，図22に典型的な実 験結果を示す。図 22 には, 被乾燥試料の含水率と装 置各部の温度がプロセス時間に対しプロットされてい る。最初 0.3 であった含水率は直線的に 0.1 まで減少 しており，恒率乾燥であることが明瞭に示されてい る。装置各部の温度は, 入口空気 $160^{\circ} \mathrm{Cが,} \mathrm{ドラフト}$ チューブを上に行った位置ほど $20-30^{\circ} \mathrm{C}$ 刻みで減少 している。Nemeth ら ${ }^{39)}$ は，1983年に乾燥機として の噴流層のスケールアップと改良について報告した。 その中に，外筒の半分程度の内筒を備えた噴流層型乾 燥装置が “A novel type spouted bed dryer equipped with an inner cylinder”という表現で紹 介されている。高含水率物質の乾燥をはじめとする大 量の空気を送る必要がある場合にとられた改良策であ る。通常のドラフトチューブより少し径比（外筒に対 する）が大きく，ドラフトチューブという名も冠され ていないが，その特性からしてドラフトチューブ付き 噴流層といってよいと思われる。ドラフトチューブ付 き噴流層の乾燥装置への応用に関しては, 見出せた限 りこれが最も古い報告である。最初のドラフトチュー ブ付き噴流層に関する報告は, 冒頭で触れたとおり，

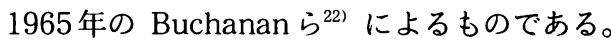

乾燥の原動力は大部分が加熱空気から供給される熱 であるが，上述のように 1 件だけ高周波加熱を用いた 報告 ${ }^{37)}$ が見うけられる。加熱空気による乾燥は, 空 気から穀類外表面への熱移動と, 穀類外表面からバル クへの水の移動との釣り合いにより生じており, 通常 の恒率乾燥もしくは減率乾燥で記述されるはずであ る。すなわち, 乾燥速度は加熱空気から穀類粒子外表

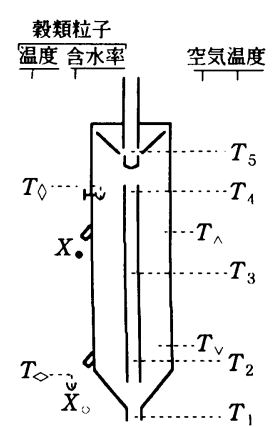

(a)

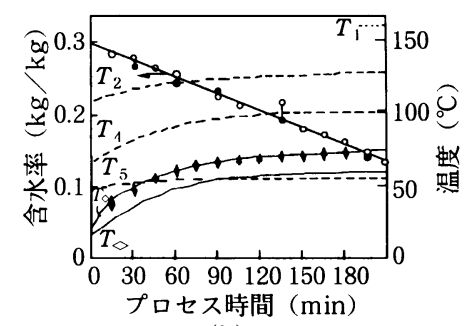

(b)

図22 (a) 各測定点の位置 : $T_{1}-T_{5}$, チューブ内の空気 温度； $T_{\wedge}, T_{\vee}$, 環状部の空気温度 ; $T_{\diamond}, T_{\diamond}$, 環状部の穀類粒子の温度 ; $X_{\bullet}, X_{0}$ ，穀類粒子の 含水率

（b）穀類含水率と装置各部の温度の経時变化

面への熱移動, 及び粒子内の熱移動に律されることに なる。一方，加熱に高周波を用いると，被加熱物質に 加わる単位時間あたりの熱量は高周波の出力そのもの なので，熱移動の制約からは逃れられるという利点を 持つ。当然, 粒子外表面近傍に乾燥層ができて本来な ら減率乾燥になる領域でも, 恒率乾燥的な特性を示す ことになろう。ただし，高周波加熱は，高周波から被 加熱物質へのエネルギー移行の特徴を知悉した上で行 われるべきであろう。例えば, 高周波用電極の形状・ 位置が挙げられる。先に紹介した論文では, 電極は, ドラフトチューブと外筒（アース側）とに設置されて いる。この場合，環状部の移動層に高周波加熱が行わ れることになる。局所的エネルギー入力は半径の二乗 に反比例するので, 例えばドラフトチューブが $10 \mathrm{~mm}$, 外筒が $100 \mathrm{~mm}$ なら, ドラフトチューブのす ぐ外を移動中の粒子は, 外筒のすぐ内を移動する粒子 の 100 倍もの熱エネルギーを受けとることになる。ド ラフトチューブのすぐ外側の粒子が受け取るエネル ギーの上限を考慮することや，スパウト部における粒 子の再分配が十分になるよう考慮することが求められ るのは言うまでもない。また，高周波加熱は余分な整 
備投資を必要とすることも事実であり，それを克服で きるような場合にのみ適用可能であろう。

第二に食品眯濁液の乾燥に関する Povrenovic らの 1991 年に発表された研究38) においては，媒体である ポリプロピレン粒子を空気循環させておき, 食品懸濁 液をドラフトチューブ直下のノズルからスプレーする 操作を想定して実験が行なわれた。懸濁液は, ポリプ ロピレン粒子表面に付着した後, ドラフトチューブ内 を上昇しながら乾燥する。こうして乾燥した食品眯濁 液由来の表面付着物は, ポリプロピレン粒子がドラフ トチューブ上部の板にたたきつけられると同時に剥が れ落ちる。ポリプロピレン粒子は環状部へ民戻り, 剥が れ落ちた乾燥食品粉末は乾燥器外に去った後サイクロ ンで捕集される。実際の実験では, 基礎的検討とし て, 食品懸濁液のかわりに蒸留水が用いられた。

2. 1.2 その他（コーティング, 混合, 粒子供給) 乾燥への応用以外では, コーティング, 混合及び粒 子供給への応用が報告されている。

Ichikawa ら ${ }^{40)}$ は， 1994 年にドラフトチューブ付 き噴流層のコーティングへの応用を報告した。内容 は, 乳糖をアクリルラテックスによりコーティング後 マイクロカプセル化するものであり, 徐放性薬剂調製 への応用である。その研究で使用されたドラフトチ ューブ付き噴流層は, 実験室規模（粒子充塡量約 $300 \mathrm{~g} ＼mathrm{~ ） 既 製 品 て ゙ あ り ， ス フ ゚ レ ー ノ ス ゙ ル か ら ラ テ ッ ~}$ クスを噴射し, 循環している乳糖粒子をコーティング するものである。その後, 加熱キュアによりカプセル 化している。

Shuck ら ${ }^{8)}$ は，1982年にドラフトチューブ付き噴 流層の混合への応用について特許を出願した。この特 許では, 酸化ウラニウム粉に酸化プルトニウム粉を, その含有量が 2 $6 \mathrm{wt} \%$ となるように，凝集を防ぎつ つ混合するためには，ドラフトチューブ付き噴流層が 有効であるとクレームされている。粒子の大きさは $10 \mu \mathrm{m}$ 以下で, 噴流層が扱う物質としては異例に細か いものである。通常 $1 \mathrm{~mm}$ 以下の粒子は，流動層で扱 うことが一般的であるが, $10 \mu \mathrm{m}$ はその下限を下回っ ており，噴流層が有効な方法として再浮上したものと 考えられる。装置の特徴を二点紹介する。第一は, 厚 み 2 inch, 横幅 40 inch 程度の平べったい形をしてい るということである。一種の二次元噴流層であるが, 内部観察のためではなく，核燃料が臨界点を越えない ための配慮である。第二は, ドラフトチューブに内部 流れに直交する方向につけたノズルからも, 空気をド ラフトチューブ内に吹きこんでいることである。これ
は，擬集防止のためにとられた方策である。

Ferreira ら ${ }^{25)}$ は，1992年に一種のドラフトチュー ブ付き噴流層装置を固体粒子供給に応用しょうとし, 固体粒子循環量を制御するための基礎的検討を行っ た。彼らは，チューブ間距離と供給ガス速度が固体粒 子循環量に及ぼす影響を測定し, 内径 $55 \mathrm{~mm}$ のドラ フトチューブを用いた場合, $2.8 \mathrm{~mm}$ のガラスビーズ が 0.01 から $0.6 \mathrm{~kg} / \mathrm{s}$ の範囲内で自由に制御できるこ とを報告した。小径粒子 $(200 \mu \mathrm{m}$ の石英砂) に関す

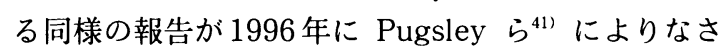
れた。

\section{2 反 応}

\section{2. 1 石炭ガス化・燃焼および都市ゴミ燃焼}

石炭ガス化 ${ }^{42 \sim 44)}$ ・燃焼 ${ }^{16)}$, 都市ゴミ燃焼 ${ }^{45)}$ に関す る応用においては, 石炭粒子もしくは都市ゴミが装置 下部から導入される空気/燃料混合ガスにより循環さ せられ，その間ガス化や酸化を受け，反応ガス及び排 ガスが装置外へ排出されるというものである。熱媒体 として砂 ${ }^{45)}$ やセラミック粒子 ${ }^{42 \sim 44)}$ が用いられた。

筆者ら ${ }^{42 \sim 44)}$ は，ここ 10 年来ドラフトチューブ付き 噴流層による，石炭のガス化プロセスに関する実験的 検討を行ってきた。石炭のガス化は, 従来, 移動層, 噴流流動層やドラフトチューブが無い噴流層によって 実施されてきた。筆者らは, ドラフトチューブ付き噴 流層が石炭水蒸気ガス化に適した装置上の特性を持つ と予測し、コールドモデル実験を経て最近のホットモ デル実験でこれを実証した。コールドモデル装置（ア クリル製) を図23に，ホットモデル装置（ステンレ ス製）を図24に，実験結果の一例を図25に示した。 このガス化装置においては, ドラフトチューブは燃焼 ガス燃焼ゾーンで, 環状部は水蒸気による石炭ガス化 ゾーンとなる。ドラフトチューブを付けたことによ り，ドラフトチューブー環状部間のガス・固体の混合 を防ぐことができた。また, 循環熱媒体として耐熱セ ラミックビーズを用いることにより，ドラフトチュー ブ内で発生する熱エネルギーを効率良く環状部に伝え ることができた。図 25 は, 最近のホットモデ実験 による生成ガスの組成である。水素を 50 \%以上含む ガスが生成したことがわかる。

成瀬ら ${ }^{16)}$ は， 1989 年に高効率石炭燃焼装置とし て, 高速流動層（石炭部分燃焼）と移動層（チャー燃 焼）とを組み合わせた装置を提案した。

Konduri ら ${ }^{45)}$ は， 1995年に都市ゴミ，下水スラッ ジ用焼却炉に関する基礎的検討を報告した。プロパン 内部燃焼により加熱が行われた装置内に $1.85 \mathrm{~mm}$ の砂 


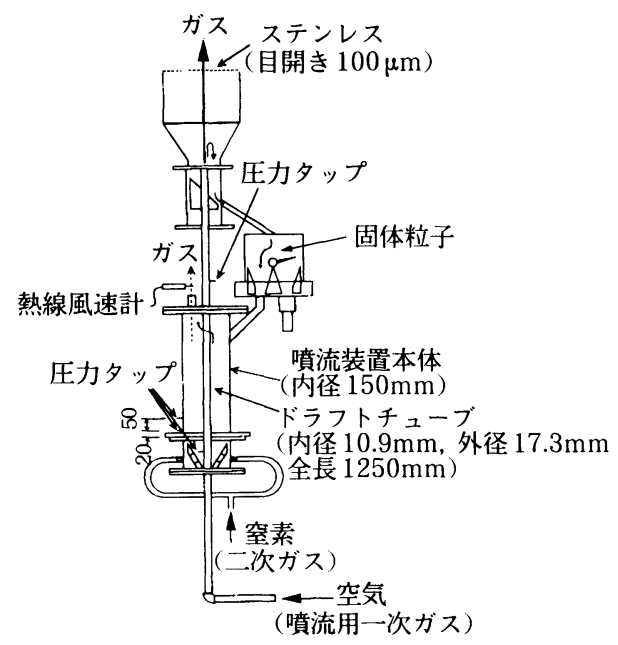

図23石炭水蒸気ガス化のためのコールドモテル 実験装置（アクリル製）の図

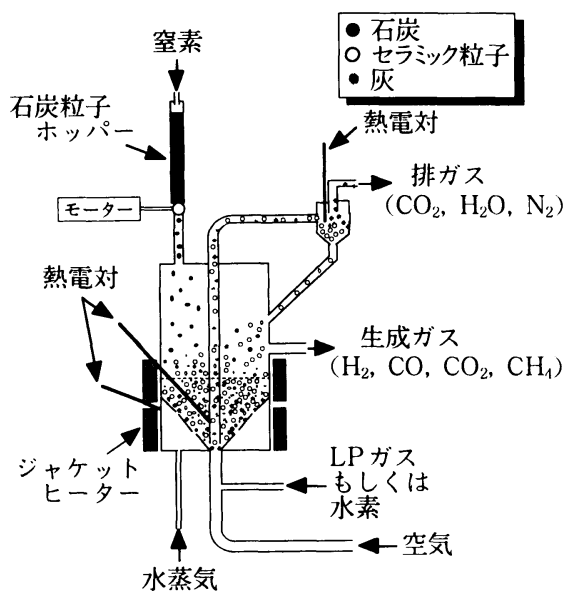

図24石炭水蒸気ガス化ホットモデル実験装置図

粒子を循環させ，環状部の滞留時間（底部形状，ドラ フトチューブの有無，環状部層高により制御）が燃料 利用効率や一酸化炭素残存率をはじめとする種々の効 率に及ぼす影響を検討した。ゴミやスラッジの模擬物 は使用されなかった。従来，焼却炉は流動層型が一般 的であり，それに関する基礎的検討も多く報告されて いる。しかしながら，噴流層に関する報告はそう多く ない。特に，ドラフトチューブ付き噴流層による焼却 炉の基礎研究に関しては Konduri らの報告が唯一見 出せたものである。噴流層の流動層に対する優位性 は, $\mathrm{NO}_{\mathrm{x}}$ のコントロールと燃料選択に巾があること である。

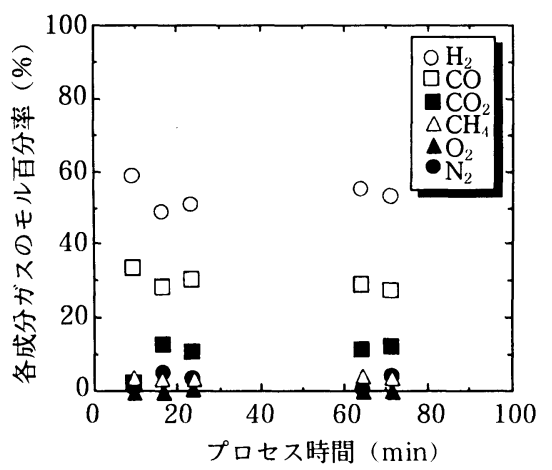

図25 石炭水蒸気ガス化の実験結果 (環状部出口ガスの組成)

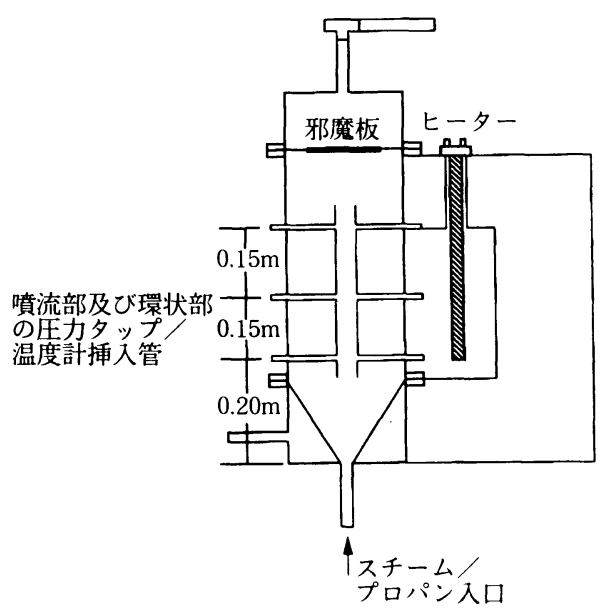

図26パイロットスケールのプロパン熱分解用 水蒸気噴流層装置図

\section{2.2 炭化水素の熱分解}

前節の石炭のガス化・燃焼においては，固体の石炭 粒子が装置内を循環もしくは通過する間に酸化剤ガス (酸素) やガス化剂ガス (水蒸気) と接触し, 反応す るものである。これらの場合, 粒子表面での気固反応 速度が比較的遅いため, ガス化の場合反応の場は環状 部であり，燃焼の場合反応が終了するまで石炭粒子が 循環し続けるというものである。一方，低級炭化水素 の熱分解は比較的早く，100ミリ秒オーダーの滞留時 間で充分である。そこで，固体触媒粒子が装置内を循 環し，反応ガスはドラフトチューブ内を高速でただ一 度通過するというプロセスが構築21.46) された。

Stocker ら ${ }^{46)}$ は，1989年にドラフトチューブ付き 噴流層による，プロパンの高速熱分解を報告した。ジ ヤケットヒーターで所定温度に保たれた装置内（図26） 


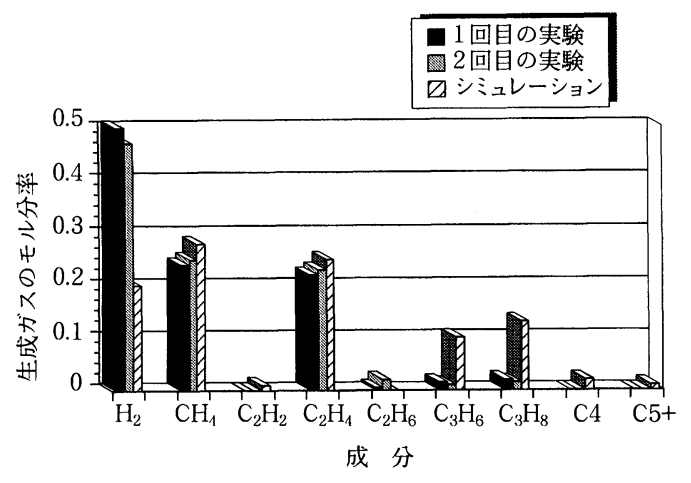

図27 パイロットスケール装置によるプロパン熱分解 実験結果（生成物の組成）とシミュレーション との比較

で, 直径 $1 \mathrm{~mm}$ の石英砂が水蒸気により循環している 中, プロパンが反応原料として送り込まれた。層温度 を変えて 3 条件下 $\left(720,790,880^{\circ} \mathrm{C}\right)$ で実験が実 施された。図 27 にその結果を示すように, 反応温度 $880^{\circ} \mathrm{C}$ で, 水素, メタン及びエタンが高収率で得られ た。このことから，ドラフトチューブ付き噴流層は, 高速気相反応を始めとする滞留時間が制限的な因子と なるような応用に，適していることが実証されたと言 える。Eng ら ${ }^{21)}$ が1989年に発表した論文も，上述の ものと同じくプロパンの高速熱分解をテーマにしたも のである。内容は主としてシミュレーションであり, データはすべて1987年に発表された Stocker の学位 論文 ${ }^{47)}$ からのものである

\section{2.3 二酸化硫黄の接触酸化}

Ryan ら ${ }^{48)}$ は，1969年にドラフトチューブ付き噴 流層による二酸化硫黄の三酸化硫黄への接触酸化を報 告した。送入ガスが反応原料であり且つワンパスで装 置内を通り抜けるという点では，2.2.2 項の炭化水 素の熱分解と同様の操作であるが, Ryan らがドラフ トチューブ付き噴流層を適用するに至った理由は，炭 化水素の熱分解の場合とは全く異なっている。従来,
二酸化硫黄の酸化は固定層で行われてきたが, 固定層 では，圧損の観点から粒子径や流速に制限があり，そ れを軽減できる流動層ではバックミキシングという問 題が生じる。そこで, 彼らはドラフトチューブ付き噴 流層の適用を試み, $100 \mu \mathrm{m}$ 程度の酸化チタン触媒循 環下で二酸化硫黄の三酸化硫黄への酸化を行った。 $475^{\circ} \mathrm{C} て ゙$ 最も大きな転化率 $50 \%$ が得られた。この温 度下での固定層での反応成績はほとんど平衡転化率 $95 \%$ \%゙り，Ryan らの低転化率は滞留時間の不足 によるものと考えられる。

おわりに

ドラフトチューブ付き噴流層に関する最近の研究に ついて調査し，流動・伝熱特性及び応用例についてそ の結果をまとめてみた。本文中何度も述べたように, 従来型の噴流層を「ドラフトチューブ付き」とするこ とで，噴流層や流動層のもつ不規則な混合流れが規則 性（均一性）を持つ流れに変えられたという点で, 全 く異なる装置になったと考えても良いと思われる。し かしながら，ドラフトチューブ付き噴流層の応用技術 は, 主として噴流層の延長や改善という形で発展して きたので，噴流層 $\rightarrow$ ドラフトチューブ付き噴流層とい う発想からのものが多い。その中では, 我々が現在開 発中の石炭ガス化装置のようにプロセスを実現するた めに広範な反応装置群から, 最も反応効率を上げるた めの装置という観点から，ドラフトチューブ付き反応 器を選択したのは特異的といえるものである。

ドラフトチューブ付き噴流層装置はガスや粒子群の 均一的な流れが実現でき, しかもそれらが装置上から も操作条件からも，ある程度制御できる（この方面へ の今後の研究が待たれているのが現状であるが）とい う二つの大きな特長を持っており, それが決定的に重 要な多くのプロセスにとっては, 極めて有力な装置と してもう少し注目されて良いと思われる。

\section{Nomenclature}
$A r$ : アルキメデス数
$C_{\mathrm{pg}}$ : ガスの熱容量
$C_{\mathrm{ps}}$ : 粒子の熱容量
$D_{\mathrm{C}}$ : 塔径
$D_{\mathrm{n}}$ : 入口ノズル径
$D_{\mathrm{p}}$ ：平均粒子径
$D_{\text {小 }}$ : ドラフトチューブ径
$g$ : 重力加速度
$G_{\mathrm{S}}$ : 粒子循環量

$\begin{array}{rll}(-) & h & : \text { 伝熱係数 } \\ \left(\mathrm{J} /\left(\mathrm{kg} \cdot{ }^{\circ} \mathrm{C}\right)\right) & H & : \text { 静止層高 } \\ \left(\mathrm{J} /\left(\mathrm{kg} \cdot{ }^{\circ} \mathrm{C}\right)\right) & \left.H_{\mathrm{D}}\right) & : \text { チューブ間距離 } \\ (\mathrm{m}) & K & : \text { 熱損失係数 } \\ (\mathrm{m}) & L_{\mathrm{c}} & : \text { 塔高さ } \\ (\mu \mathrm{m}) & L_{\mathrm{T}} & : \text { ドラフトチューブ長さ } \\ (\mathrm{m}) & N u & : \text { ヌッセルト数 } \\ \left(\mathrm{m} / \mathrm{s}^{2}\right) & m & : \text { 空気の質量速度 } \\ \left(\mathrm{kg} /\left(\mathrm{m}^{2} \cdot \mathrm{s}\right)\right. & M & : \text { 粒子充坥量 }\end{array}$

$\left(\mathrm{W} /\left(\mathrm{m}^{2} \cdot{ }^{\circ} \mathrm{C}\right)\right)$

(m)

$(\mathrm{mm})$

$\left(\mathrm{W} /{ }^{\circ} \mathrm{C}\right)$

(m)

(m)

$(-)$

$(\mathrm{kg} / \mathrm{s})$

(kg) 
$\Delta P_{\mathrm{D}}:$ チューブ内圧力損失

$\Delta P_{\mathrm{S}}$ : ドラフトチューブ付き噴流層の圧力損失

$Q_{1}:$ 補助ガス流量

$Q_{\mathrm{T}} \quad:$ 入口ガス流量

$Q_{\wedge}:$ アニュラス部ガス流量または流量パーセント

$T$ : 温度

$t \quad:$ プロセス時間

$T_{\mathrm{a}}$ : 外界の温度

$T_{\mathrm{b}}$ ：層温度

$T_{\mathrm{e}} \quad:$ ガス出口温度

$T_{\mathrm{i}}$ : ガス入口温度

$\begin{array}{rll}(\mathrm{Pa}) & U & : \text { 入口ガス空塔速度 } \\ (\mathrm{Pa}) & U_{\mathrm{ms}} & : \text { 最小噴流化速度 } \\ \left(\mathrm{m}^{3} / \mathrm{s}\right) & U_{\mathrm{mss}}: \text { 最小安定噴流化速度 } \\ \left(\mathrm{m}^{3} / \mathrm{s}\right) & Z & : \text { チューブ高さ } \\ & \beta & : \text { 多孔質チューブの開口率 } \\ \left(\mathrm{m}^{3} / \mathrm{s}, \%\right) & \gamma & : \text { 熱伝導度 } \\ \left({ }^{\circ} \mathrm{C}\right) & \varepsilon & : \text { 空隙率 } \\ (\mathrm{s}) & \eta & : \text { 接触効率 } \\ \left({ }^{\circ} \mathrm{C}\right) & \theta & : \text { 円錐部開角 } \\ \left({ }^{\circ} \mathrm{C}\right) & \mu_{\mathrm{f}} & : \text { ガス粘度 } \\ \left({ }^{\circ} \mathrm{C}\right) & \rho_{\mathrm{f}} & : \text { ガス密度 } \\ \left({ }^{\circ} \mathrm{C}\right) & \rho_{\mathrm{p}} & : \text { 粒子密度 }\end{array}$

$(\mathrm{m} / \mathrm{s})$

$(\mathrm{m} / \mathrm{s})$

$(\mathrm{m} / \mathrm{s})$

(m)

(\%)

$\left(\mathrm{W} /\left(\mathrm{m} \cdot{ }^{\circ} \mathrm{C}\right)\right)$

$(-)$

$(-)$

$(\mathrm{deg})$

$(\mathrm{Pa} \cdot \mathrm{s})$

$\left(\mathrm{kg} / \mathrm{m}^{3}\right)$

$\left(\mathrm{kg} / \mathrm{m}^{3}\right)$

\section{References}

1) Mathur, K. B. and P. E. Gishler : AIChE J., 1, 157-164 (1955)

2) Mathur, K. B. and N. Epstein : "Spouted Beds," Academic Press, New York (1974)

3) Whiting, K. J. and D. Geldart : Chem. Eng. Sci., 35, 1499-1501 (1980)

4) Mujumdar, A. S : "Drying '84," Ed. by Mujumdar A. S. and S. Arun, p. 151-157 (1984)

5) Law-Kwet-Cheong, L., K. Malhotra and A. S. Mujumdar : Powder Technol., 46, 141-148 (1986)

6) Kalwar, M. I., G. S. V. Raghavan and A. S. Mujumdar : Can. J. Chem. Eng., 70, $887-894$ (1992)

7) Kalwar, M. I. and G. S. V. Raghavan : Powder Technol., 77, 233-242 (1993)

8) Shuck, D. L. and I. E. Kundsen : United States Patent 4, 577, 972 (1986)

9) Milne, B. J., F. Berruti, L. A. Behie, D. Bruijn and J. W. Theo : Can. J. Chem. Eng., 70, 910-915 (1992)

10) Claflin, J. K. and A. G. Fane : AIChE, Symp. Ser. $80,17-23(1984)$

11) Takeda, K. and H. Hattori : Kagaku Kogaku Ronbunshu, 1, 149-154 (1975)

12) Hattori, H. and K. Takeda : J. Chem. Eng. Japan, 11, 125-129 (1978)

13) Hattori, H., A. Kobayashi, I. Aiba and T. Koda: $J$. Chem. Eng. Japan, 17, 102-103 (1984)

14) Kim, S. J. : Korean J. Chem. Eng., 7, 74-80 (1990)

15) Hattori, H. and T. Nagai : J. Chem. Eng. Japan, 29, 484- 487 (1996)

16) Naruse, I., H. Matsuda and M. Hasatani : Kagaku Kogaku Ronbunshu, 15, 105-112 (1989)

17) Freire, J. T., L. A. P. Freitas and A. C. Pinhati : Exp. Heat Transfer, Fluid Mech. Thermodyn. 1993, Proc. World Conf., 3rd, 2, 1583-1587 (1993)

18) Barrett, N., J. Claflin, A. G. Fane and R. A. Mitchell : CHEMECA '83, 531-538 (1983)

19) Claflin, J. K. and A. G. Fane : Drying ' 84 , 137-141 (1984)

20) Stocker, R. K., J. H. Eng and L. A. Behie : Can. J. Chem. Eng., 68, 302-311 (1990)

21) Eng, J. H., W. Y. Svrcek and L. A. Behie : Ind.
Eng. Chem., Res., 28, 1778-1785 (1989)

22) Buchanan, R. H. and B. Wilson : Mech.\& Chem. Eng. Trans., 1, 117-124 (1965)

23) Ishikura, T. and H. Okada : Fukuoka Daigaku Kogaku Shuho, 52, 133-142 (1994)

24) Ijichi, K., Y. Tanaka and K. Yoshida : Kagaku Kogaku Ronbunshu, 14, 566-570 (1988)

25) Ferreira, M. C. and J. T. Freire : Can. J. Chem. Eng., 70, 905-909 (1992)

26) Hattori, H., K. Tanaka and K. Takeda : J. Chem. Eng. Japan, 14, 462-466 (1981)

27) Grbavcic, Z. B., D. V. Vukovic, S. D. Jovanovic, R. V. Garic, Dz. E. Hadzismajlovic, H. Littman and H. H. Morgan III : Can. J. Chem. Eng., 70, 895-904 (1992)

28) Ijichi, K., Y. Tanaka, Y. Uemura, Y. Hatate and K. Yoshida : Kagaku Kogaku Ronbunshu, 16, 924-930 (1990)

29) Yang, W. C. and D. L. Keairns : Can. J. Chem. Eng., 61, 349-355 (1983)

30) Claflin, J. K. : CHEMECA '82 : Resour. Dev. Eighties, Aust. Chem. Eng. Conf., 10th, p. 115-120 (1982)

31) Claflin, J. K. and A. G. Fane : Can. J. Chem. Eng., 61, 356-363 (1983)

32) Matthew, M. C., M. H. Morgan III and H. Littman : Can. J. Chem. Eng., 66, 908-918 (1988)

33) Muir, J. R., F. Berruti and L. A. Behie : Chem. Eng. Comm., 88, 153-171 (1990)

34) Khoe, G. K. and J. Van Brakel : Can. J. Chem. Eng., 61, 411-418 (1983)

35) Naruse, I., H. Matsuda and M. Hasatani : Kagaku Kogaku Ronbunshu, 13, 671 (1987)

36) Ishikura, T., H. Nagashima and M. Ide : Kagaku Kogaku Ronbunshu, 22, 615 (1996)

37) Colley, M. I. : Drying Technol., 11, 355-368 (1993)

38) Povrenovic, D. S., Z. B. Grbavcic, Dz. E. Hadzismajlovic, D. V. Vukovic and H. Littman : Drying '91, 7th Meeting, 343-351 (1991)

39) Nemeth, J., E. Pallai and E. Aradi : Can. J. Chem. Eng., 61, 419-425 (1983)

40) Ichikawa, H., H. Tokumitsu, K. Jono, T. Fukuda, 
Y. Osako and Y. Fukumori : Chem. Pharm. Bull., 42, 1308-1314 (1994)

41) Pugsley, T. S., B. J. Milne and F. Berruti : Powder Technol., 88, 123-131 (1996)

42) Hatate, Y., H. Mihara, K. Ijichi, T. Yoshimi, S. Arimizu, Y. Uemura and D. F. King : Kagaku Kogaku Ronbunshu, 22, 1180-1184 (1996)

43) Hatate, Y., Y. Uemura, S. Tanaka, T. Tokumasu, Y. Tanaka, D. F. King and K. Ijichi : Kagaku Kogaku Ronbunshu, 20, 758-765 (1994)

44) Uemura, Y., M. Miyauchi, S. Tanaka, K. Ijichi, Y.
Tanaka, D. F. King and Y. Hatate : Prepr. Pap, Am. Chem. Soc., Div. Fuel Chem., 37, 1972-1976 (1992) 45) Konduri, R. K., E. R. Altwicker and M. H. Morgan III : Can.J. Chem. Eng., 73, 744-754 (1995)

46) Stocker, R. K., J. H. Eng, W. Y. Svrcek and L. A. Behie : AIChE J., 35, 1617-1624 (1989)

47) Stocker, R. K. : Ph. D. Thesis, University of Calgary, Calgary, Alberta (1987)

48) Ryan, W. J. and U. A. Heinzle : AMDEL Bull., 8, 1-9 (1969) 